\title{
RISK PERCEPTION AND ALCOHOL DRINKING AMONG YOUNG PEOPLE IN SEVEN EUROPEAN COUNTRIES FROM 1995 TO 2015
}

\section{PERCEPCJA RYZYKA A PICIE ALKOHOLU WŚRÓd MŁODZIEŻY W SIEDMIU KRAJACH EUROPEJSKICH W LATACH 1995-2015}

\author{
Michał Bujalski, Janusz Sierosławski \\ Institute of Psychiatry and Neurology, Department of Studies on Alcoholism and Drug Dependence, Warsaw, Poland \\ Instytut Psychiatrii i Neurologii, Zakład Badań nad Alkoholizmem i Toksykomaniami, Warszawa, Polska
}

Alcohol Drug Addict 2018; 31 (1): 17-48 DOI: https://doi.org/10.5114/ain.2018.78815

\begin{abstract}
Introduction: Risk perception may essentially affect alcohol consumption and binge drinking. Understanding the impact and the role of risk perception is an important factor in the effectiveness of youth-targeted alcohol prevention. The aim of research was to analyse changes in risk perception and trends in alcohol drinking among school students in Poland in comparison to youth from other European countries from 1995 to 2015.

Material and methods: ESPAD study data (19952015) from Poland, the Czech Republic, Denmark, France, Sweden, Italy and Ukraine were analysed $(N=144,357)$ to examine the link between risk perception and alcohol consumption and binge drinking. Data were analysed with IBM SPSS 21 using Chi-square tests.
\end{abstract}

\begin{abstract}
Streszczenie
Wprowadzenie: Percepcja ryzyka może mieć zasadniczy wpływ na sięganie po alkohol oraz upijanie się. Zrozumienie wpływu i roli percepcji ryzyka jest ważne w kontekście efektywności działań profilaktycznych skierowanych do młodzieży. Celem badania było przeanalizowanie zmian $\mathrm{w}$ percepcji ryzyka oraz trendów w konsumpcji alkoholu w latach 1995-2015 wśród młodzieży szkolnej w Polsce na tle innych krajów europejskich.

Materiał i metody: Analizowano dane z badań ESPAD, realizowanych w Polsce, Czechach, Danii, Francji, Szwecji, Włoszech i na Ukrainie w latach 1995-2015 ( $N=144357)$. W badaniu analizowany był związek percepcji ryzyka $\mathrm{z}$ piciem i upijaniem się. Analizy statystyczne przeprowadzono z użyciem oprogramowania IBM SPSS 21, wykorzystując testy chi-kwadrat.
\end{abstract}

\footnotetext{
Correspondence to/Adres do korespondencji: Michał Bujalski, Instytut Psychiatrii i Neurologii, Zakład Badań nad Alkoholizmem i Toksykomaniami, ul. Sobieskiego 9, 02-957 Warszawa, phone: 48224582 784; e-mail: bujalski@ipin.edu.pl

Authors' contribution/Wkład pracy autorów: Study Design/Koncepcja badania: M. Bujalski; Data Collection/Zebranie danych: J. Sierosławski; Statistical analysis/Analiza statystyczna; Data Interpretation/Interpretacja danych: M. Bujalski; Acceptance of final manuscript version/Akceptacja ostatecznej wersji pracy: M. Bujalski, J. Sierosławski; Literature Search/Przygotowanie literatury: M. Bujalski; Funds collection/Pozyskanie środków (finansowania): J. Sierosławski

No ghostwriting and guest authorship declared./Nie występują zjawiska ghostwriting i guest authorship.

Submitted/Otrzymano: 10.04.2018 • Accepted/Przyjęto do druku: 17.07.2018
} 
Results: Between 1995 and 2015, the percentage of students who considered frequently drinking small amounts of alcohol as a low-risk or no-risk behaviour increased in some of the countries (including Poland). Changes in risk perception of binge drinking were of less dramatic course, however significantly affected the magnitude of this phenomenon.

Discussion: The impact of risk perception on alcohol consumption changes over time and might occur differently across countries. The declining rate of drinking students is not always related to the increase of high risk perception. In recent years, frequently drinking small amounts of alcohol has not become perceived as a risky behaviour.

Conclusions: Analysis of associations of risk perception and alcohol related behaviours among young people, emphasises the need to introduce the issues of frequent consumption of small amounts of alcohol into prevention programmes.

Keywords: Alcohol, Risk, Risk perception, Young people, ESPAD study
Wyniki: W latach 1995-2015 odsetek uczniów, którzy oceniali częste spożywanie niewielkich ilości alkoholu jako mało ryzykowne bądź pozbawione ryzyka, wzrastał w części krajów (w tym w Polsce). Zmiany percepcji ryzyka upijania się miały mniej gwałtowny przebieg, jednak znacząco wpływały na skalę tego zjawiska.

Omówienie: Wpływ percepcji ryzyka na sięganie po alkohol zmienia się w czasie i może mieć odmienny przebieg w różnych krajach. Ograniczenie odsetka uczniów sięgających po alkohol nie zawsze wiąże się ze wzrostem wysokich ocen ryzyka. W ostatnich latach częste spożywanie niewielkich ilości alkoholu przestaje być postrzegane jako zachowanie ryzykowne.

Wnioski: Analiza związków percepcji ryzyka i zachowań związanych $\mathrm{z}$ alkoholem wśród młodzieży świadczy o potrzebie włączenia do programów profilaktycznych zagadnień związanych z częstym spożywaniem niewielkich ilości alkoholu.

Słowa kluczowe: alkohol, ryzyko, percepcja ryzyka, młodzież, badanie ESPAD

\section{- INTRODUCTION}

\section{Issue of risk perception}

Risk perception, defined as an individually perceived vulnerability towards risk [1], plays an important role in an individual's decision-making process, $[2,3]$ and can have a major impact on alcohol-related behaviours [4-7]. Analyses of risk perception and of psychoactive substance use are an integral part of the studies on the effects of public health policy and aim of preventive activities $[1,6,8-10]$. This issue is particularly relevant when taking into account underage drinkers who learn alcohol-related behaviours, which affects both their consumption level, drinking patterns and the decisions on alcohol use initiation.

The results of empirical research show that the perception of individual risk correlates with alcohol consumption. Persons who abuse it are characterised by a low risk perception $[6,11]$, with individual risk being generally perceived as lesser compared to risk assessment of the same behaviour in the social dimension [3]. Although psychometric tests prove that an individual usually

\section{- WpRoWAdZENIE}

\section{Zagadnienie percepcji ryzyka}

Percepcja ryzyka - indywidualnie postrzegana podatność na zagrożenie [1] - odgrywa ważną rolę $\mathrm{w}$ procesach decyzyjnych jednostek $[2,3]$ i może mieć zasadniczy wpływ na zachowania związane $\mathrm{z}$ alkoholem [4-7]. Analizy percepcji ryzyka i używania substancji psychoaktywnych stanowią integralną część badań nad efektami polityki zdrowia publicznego oraz cel działań profilaktycznych [1, 6, 8-10]. Jest to zagadnienie szczególnie istotne $\mathrm{w}$ perspektywie problematyki picia alkoholu przez osoby niepełnoletnie, które uczą się zachowań związanych $\mathrm{z}$ alkoholem, co wpływa zarówno na poziom konsumpcji, wzory picia alkoholu, jak i na decyzje o inicjacji alkoholowej.

Wyniki badań empirycznych dowodzą, że percepcja indywidualnego ryzyka koreluje z konsumpcją alkoholu - osoby, które go nadużywają, odznaczają się niską oceną ryzyka $[6,11]$, przy czym indywidualne ryzyko jest na ogół postrzegane jako mniejsze $\mathrm{w}$ porównaniu z oceną ryzyka tego samego zachowania w wymiarze społecznym [3]. Pomimo że badania psychometryczne dowodzą, iż jednostka 
rationally evaluates risk $[12,13]$, alcohol risk assessments are deeply differentiated. The differences between safe and risk alcohol use are generally unclear and multi-dimensional [14]. They are based on heuristics and a reduction of the phenomenon's complexity: problem is oversimplified and presented "roughly" (e.g. "frequent drinking is harmful"). Context, experience of emotions and threat levels are key factors in risk perception: certain risk representation is formed based on these factors $[13,15]$.

Cognitive structure components and attitudes towards risk are determined by rules of social discourse as well as cultural factors [16-21]. Culture creates a context of risk identifying, selecting and interpreting, shaping seemingly "irrational" choices of individuals and their moral evaluations. Threat selection is based on social assessments of particular phenomena and it relates to the possibility of assigning them to an existing framework for interpreting a problem: this is often accompanied by identifying its causes and possible solutions. An example could be the risk involved to the use of asbestos in construction, which has caused a backlash in public opinion against this industrial practice. This phenomenon was interpreted as stemming from the currently much discussed criticism of industrialisation which allowed to assign cancer risk to a specific perpetrator. Other causes of these diseases were trivialised due to a lack of opportunities to mobilise public opinion [18]. A similar situation took place in the case of the tobacco industry, which was blamed for the cancer epidemic. The concept of risk has ceased to be morally neutral. In modern society "risk" has replaced the concept of "sin", becoming an instrument of social control $[16,18,22]$. This process clearly made its mark in the medical area, eg. in case of the AIDS epidemic or alcohol and drug dependence.

Culture forms a framework for risk interpretation and determines attitudes, though risk perception at the individual level is never homogeneous. Differences are not an exception but rather an immanent feature of how "risk cultures" function within a given social organisation. These cultures can be defined according to grid/group schema: attitudes towards social zazwyczaj racjonalnie ocenia ryzyko $[12,13]$, to oceny ryzyka związanego $\mathrm{z}$ alkoholem są głęboko zróżnicowane. Różnice między bezpiecznym a ryzykownym piciem alkoholu są na ogół niejasne i wielowymiarowe [14], oparte na heurystykach i redukcji złożoności danego zjawiska polegającej na ujmowaniu problemu „Z grubsza” (np. „częste picie alkoholu jest szkodliwe”). W percepcji ryzyka duże znaczenie ma kontekst, przeżywanie emocji oraz stopień zagrożenia - na ich podstawie tworzona jest określona reprezentacja ryzyka $[13,15]$.

Komponenty struktur poznawczych i postawy wobec ryzyka są determinowane przez reguły dyskursu społecznego i czynniki kulturowe [16-21]. Kultura tworzy kontekst identyfikacji, selekcji i interpretacji ryzyka, kształtując pozornie „irracjonalne" wybory jednostek oraz ich oceny moralne. Selekcja zagrożeń odpowiada społecznym ocenom zjawisk i jest związana $\mathrm{z}$ możliwością przypisania ich do istniejących ram interpretacji problemu, czemu często towarzyszy wskazanie jego przyczyn i ewentualnych rozwiązań. Przykładem niech będzie tu ryzyko związane ze stosowaniem azbestu w budownictwie, które wywołało stanowcze reakcje opinii publicznej wymierzone w działalność przemysłu. Zjawisko to było interpretowane jako efekt obecnej w dyskursie publicznym krytyki industrializacji, która pozwoliła na przypisanie ryzyka powstawania chorób nowotworowych konkretnemu sprawcy, podczas gdy inne przyczyny tych chorób schodziły na dalszy plan ze względu na brak możliwości mobilizacji opinii publicznej [18]. Podobna sytuacja miała miejsce w przypadku przemysłu tytoniowego, obwinianego za epidemię chorób nowotworowych. Kategoria ryzyka przestała być neutralna moralnie; w nowoczesnym społeczeństwie „ryzyko” zastąpiło kategorię „grzechu”, stając się instrumentem kontroli społecznej [16, 18, 22]. Proces ten zaznaczył się wyraźnie w obszarze zdrowia, np. w przypadku epidemii AIDS bądź uzależnienia od alkoholu i narkotyków.

Kultura stanowi ramy interpretacji ryzyka i determinuje postawy, jednak percepcja ryzyka na poziomie indywidualnym nigdy nie jest jednolita. Różnice nie stanowią wyjątku, lecz są immanentną cechą funkcjonowania „kultur ryzyka” w obrębie danej organizacji społecznej. Kultury te można określić według dwóch krzyżujących się osi zmiennych: postaw wobec kontroli społecznej 
control and social commitment ${ }^{1}$ [18]. Empirical research results indicate that in the case of individual health risks (e.g. risk perception of AIDS) high risk perception characterised people with a deep-seated social sensitivity as well as individuals for whom power and expert knowledge authorities play an important role. Low risk perception characterised representatives of individualistic culture [23]. Identifying the belonging to a given risk culture may be crucial for the effective risk communication, and by extension for the effective preventive activities [24].

\section{Research on risk perception among youth}

Many people currently believe that proper preventive or educational activities could help reduce problems related to alcohol abuse: especially those addressed to young people. However, young people's knowledge about the risks of psychoactive substance use is limited. The results of research in Sweden indicate that young people may overstate the risk of serious alcohol-related problems, such as the risk of alcohol dependence. They overestimate such beliefs regardless of whether they consume alcohol or are abstainers. Risk perception decreases with age: older students are less likely to perceive the risk as high, though adolescents who participated in preventive programmes assessed the risk as lower compared to those who did not participate [9].

The results of longitudinal studies indicate that changes in risk assessment associated with

\footnotetext{
${ }^{1}$ These cultures can be determined on the basis of two coordinates (the so-called grid/group schema): social control and commitment. Based on this graph, four types of risk culture are distinguished: fatalism, hierarchy, egalitarianism, and individualism. Fatalists avoid social commitment, but submit to authority. Representatives of hierarchical culture are guided by the strength of authority and the importance of social problems and relationships. Egalitarians are characterised by interest in social problems, but are critical of hierarchical social relations. The final group, individualists, avoid social commitment and hierarchical social structures. In each of these groups a different risk assessment is made: fatalists and people with hierarchical attitudes base their information on official sources and expert knowledge, but differ in their level of risk interest. Egalitarians are interested in the prevention of risk, but they are suspicious of information coming from public or expert institutions. Conversely individualists don't perceive risk as a threat, but rather see it as a chance.
}

oraz zaangażowania społecznego ${ }^{1}$ [18]. Wyniki badań empirycznych wskazują, że w przypadku indywidualnego ryzyka zdrowotnego (np. percepcji ryzyka AIDS) wysoka percepcja ryzyka cechuje osoby o silnej wrażliwości społecznej oraz te, dla których ważną rolę odgrywa autorytet władzy i wiedzy eksperckiej, podczas gdy niska - przedstawicieli kultury indywidualistycznej [23]. Identyfikacja przynależności do danej kultury ryzyka może być kluczowa dla efektywności komunikacji ryzyka, a co za tym idzie - skuteczności działań profilaktycznych [24].

\section{Badania nad percepcją ryzyka wśród młodzieży}

Obecnie często można spotkać się z opinią, że odpowiednio prowadzona działalność profilaktyczna bądź edukacyjna, w szczególności ta skierowana do młodzieży, może przyczynić się ograniczenia problemów związanych $\mathrm{z}$ nadużywaniem alkoholu. Wiedza na temat postrzegania ryzyka używania substancji psychoaktywnych przez młodzież jest jednak ograniczona. Wyniki badań prowadzonych w Szwecji wskazują, że młodzież może przeceniać ryzyko powstania poważnych problemów związanych $\mathrm{z}$ alkoholem, takich jak ryzyko uzależnienia od alkoholu. Dzieje się tak bez względu na fakt spożywania alkoholu bądź abstynencji. Percepcja ryzyka obniża się wraz z wiekiem - starsi uczniowie rzadziej postrzegają ryzyko jako wysokie, jednak młodzież, która uczestniczyła w zajęciach profilaktycznych oceniała ryzyko jako niższe, w porównaniu z tymi, którzy w nich nie uczestniczyli [9].

\footnotetext{
${ }^{1}$ Kultury te można określić na podstawie dwóch współrzędnych (tzw. grid/group schema): kontroli społecznej oraz zaangażowania społecznego. W ten sposób zostają wyróżnione cztery typy kultury ryzyka: fatalizm, hierarchia, egalitaryzm, indywidualizm. Fataliści unikają zaangażowania społecznego, lecz podporządkowują się autorytetom. Przedstawiciele kultury hierarchicznej kierują się siłą autorytetu oraz wagą problemów i relacji społecznych. Egalitaryści odznaczają się zainteresowaniem problemami społecznymi, ale są nastawieni krytycznie wobec hierarchicznych relacji społecznych. Ostatnia z grup - indywidualiści - unikają zaangażowania społecznego i hierarchicznych struktur społecznych. W każdej z tych grup dokonuje się odmienna ocena ryzyka: fataliści i osoby o postawach hierarchicznych opierają się na informacjach pochodzących ze źródeł oficjalnych oraz wiedzy eksperckiej, różni ich jednak stopień zainteresowania ryzykiem. Egalitaryści są zainteresowani prewencją ryzyka, lecz jednocześnie podchodzą nieufnie do informacji płynących z instytucji publicznych bądź eksperckich. Z kolei indywidualiści nie postrzegają ryzyka jako zagrożenia, widzą w nim szansę.
} 
psychoactive substances affects their future consumption. Therefore, the risk reappraisal mechanism plays an important role. This appears as a result of experience with the use of substances, e.g. using "less harmful" cigarettes, denying that the risk exists, the optimistic perspective of controlling ones addiction, and the possibility of quitting it. The status of substances also plays an important role (legal substances are rated as less risky), but there may be secondary effects due to cognitive dissonance. The risk perception associated with alcohol affects its level of consumption, however this relationship may decline or disappear over time [25].

Risk perception is one of a number of issues analysed in the European School Survey Project on Alcohol and Other Drugs (ESPAD). Previous analyses of ESPAD studies results have shown that alcohol-related risk is rated as high among abstainers and those who are experimenting with alcohol. Regular drinkers meanwhile perceive the risk as low but at the same time perceive the risk of illicit psychoactive substances as high. Prevalence and patterns of consumption are linked with differences between countries [26, 27]. Data analysis from 35 countries participating in ESPAD studies between 1999 and 2003 showed that the higher the alcohol and cannabis consumption, the less often these substances were perceived as very harmful [28]. During this same period the number of students who rated drinking large doses of alcohol on a single occassion as very risky went down. To some extent, this contributed to the general downward trend in the risk assessment of psychoactive substances, while their consumption increased (alcohol, tobacco, cocaine, marijuana, LSD, amphetamine, ecstasy, and inhalants) [29].

Data from ESPAD survey indicates a clear inverse correlation of risk perception and alcohol consumption in countries where alcohol plays an important cultural role (e.g. beer) and where traditions associated with the alcohol industry are present (in particular the brewing industry). They seen as part of historical heritage, such as in the Czech Republic and Denmark. These phenomena are usually accompanied by tolerant attitudes towards drinking and a liberal policy towards psychoactive substances as well as high rates of alcohol consumption [30]. The aforementioned results emphasise the role of cultural determinants in risk
Wyniki badań podłużnych wskazują, że zmiany w percepcji ryzyka związanego z substancjami psychoaktywnymi mają wpływ na ich konsumpcję w przyszłości, jednak istotną rolę odgrywa mechanizm korekty ryzyka jako skutek doświadczeń z używaniem substancji (np. używanie „mniej szkodliwych" papierosów, zaprzeczanie istnieniu ryzyka, optymistyczna perspektywa kontrolowania nałogu i możliwości zerwania $\mathrm{z}$ nim). Istotną rolę odgrywa również status substancji (substancje legalne są oceniane jako mniej ryzykowne), lecz może on oddziaływać wtórnie na skutek dysonansu poznawczego. Percepcja ryzyka związanego $\mathrm{z}$ alkoholem wpływa na poziom konsumpcji, jednak związek ten może wraz $\mathrm{z}$ biegiem czasu ulec osłabieniu bądź zaniknąć [25].

Percepcja ryzyka jest jednym $\mathrm{z}$ szeregu zagadnień analizowanych $\mathrm{w}$ europejskich badaniach szkolnych ESPAD. Dotychczasowe analizy wyników badań ESPAD pokazały, że ryzyko związane z piciem alkoholu jest oceniane jako wysokie wśród abstynentów i osób eksperymentujących $\mathrm{z}$ alkoholem, podczas gdy uczniowie regularnie pijący postrzegają je jako niskie, lecz jednocześnie ryzyko używania nielegalnych substancji psychoaktywnych - jako wysokie. Różnice między krajami korespondują z rozpowszechnieniem oraz wzorami konsumpcji [26, 27]. Analiza danych z 35 krajów biorących udział w badaniach ESPAD w latach 1999-2003 wykazała, że im większa konsumpcja alkoholu i konopi, tym rzadziej te substancje są postrzegane jako bardzo szkodliwe [28]. Jednocześnie w tym samym okresie spadała liczba uczniów, którzy oceniali wypijanie jednorazowo dużych dawek alkoholu jako bardzo ryzykowne, co w pewnym stopniu wpisywało się w ogólny, spadkowy trend oceny ryzyka używania substancji psychoaktywnych, przy jednoczesnym wzroście ich konsumpcji (alkohol, tytoń, kokaina, marihuana, LSD, amfetamina, ecstasy, inhalanty) [29].

Dane z badań ESPAD wskazują na wyraźną odwrotną korelację percepcji ryzyka oraz konsumpcji alkoholu w krajach, gdzie alkohol odgrywa istotną rolę kulturową (np. piwo) oraz gdzie obecne są tradycje związane z przemysłem alkoholowym (w szczególności z przemysłem piwowarskim), postrzegane jako część dziedzictwa historycznego, jak np. w Czechach i Danii. Zjawiskom tym towarzyszą zazwyczaj tolerancyjne postawy wobec picia i liberalna polityka wobec substancji psychoaktywnych oraz wysokie wskaźniki konsumpcji alkoholu [30]. Powyższe wyniki podkreślają rolę uwarunkowań kulturowych 
perception and their impact on attitudes towards alcohol as well as their implications for preventive actions.

The problem of risk perception and its relation to young people drinking has not been systematically scientifically studied in Poland. Some elements of research on the mechanisms of risk perception pertaining to youth's consuming psychoactive substances can be found in analyses of the resilience concept: resistance to risk factors, which relate somewhat to the issue of individual risk perception [31, 32]. The above mentioned ESPAD studies provide more information regarding the relation of risk perception and alcohol consumption, nevertheless their analysis needs to be supplemented. Although the conclusions from selected editions of the ESPAD study from 1995 to 2003 allowed to identify the relations between consumption and risk perception, these trends may have changed over time. Previous studies did not include all measurements from 1995 to 2015.

The aim of this analysis is to track changes in risk perception and trends in alcohol consumption from 1995 to 2015 among school students in Poland in comparison to those from other European countries. We would also like to determine the relationship between risk assessment and alcohol consumption and their changes over the years.

\section{- Material AND methods}

The study used data from six editions of the ESPAD survey from 1995 to 2015 with 144,357 students ${ }^{2}$ aged 15-16 participated in six European Union countries: Poland, the Czech Republic, Denmark, France, Sweden and Italy. Ukraine was also included. The selection of countries used for international comparisons was a result of the limitations of the ESPAD database [33] as well as the contexts of alcohol policy. The limitations of ESPAD study data resulted from the fact that only 15 countries had performed and recorded all six measurements between 1995 and $2015^{3}$, therefore the choice of states was limited to this group. France is the only exception, which was included in the analysis despite no

\footnotetext{
${ }^{2}$ The 144357 students refer only to countries performed in this analysis.

${ }^{3}$ These were the Czech Republic, Denmark, Finland, Ireland, Iceland, Norway, Poland, Portugal, Slovakia, Slovenia, Sweden, Ukraine, Hungary, Italy, and the Faroes.
}

w percepcji ryzyka i wpływ na postawy wobec alkoholu oraz ich implikacje dla działań profilaktycznych.

Zagadnienia percepcji ryzyka oraz jej związku z konsumpcją alkoholu wśród młodzieży nie były, jak dotąd, przedmiotem systematycznej refleksji naukowej w Polsce, choć elementy badań nad mechanizmami percepcji ryzyka $\mathrm{w}$ odniesieniu do zachowań związanych z konsumpcją substancji psychoaktywnych wśród młodzieży można odnaleźć w analizach zastosowania koncepcji resilience odporności na czynniki ryzyka, która do pewnego stopnia wiąże się z problematyką indywidualnej percepcji ryzyka [31, 32]. Więcej informacji na temat związków percepcji ryzyka i konsumpcji alkoholu dostarczają dane ze wspomnianych powyżej badań ESPAD, jednak ich analiza wymaga uzupełnienia. Mimo że wnioski z wybranych edycji badań ESPAD z lat 1995-2003 pozwoliły na identyfikację mechanizmów relacji konsumpcji i percepcji ryzyka, w miarę upływu czasu trendy te mogły ulec zmianie. Dotychczasowe badania nie obejmowały bowiem wszystkich pomiarów z lat 1995-2015.

Celem niniejszej analizy jest prześledzenie zmian w percepcji ryzyka oraz trendów w konsumpcji alkoholu w latach 1995-2015 wśród młodzieży szkolnej w Polsce na tle innych krajów europejskich, a także udzielenie odpowiedzi na pytanie o związki ocen ryzyka i konsumpcji alkoholu oraz ich zmiany na przestrzeni lat.

\section{- MATERIAŁ I METOdy}

W badaniu wykorzystano dane pochodzące z sześciu edycji badań ESPAD z lat 1995-2015, w których łącznie wzięło udział 144357 uczniów ${ }^{2}$ w wieku 15-16 lat, w Polsce i w pięciu krajach Unii Europejskiej: Czechach, Danii, Francji, Szwecji i we Włoszech oraz na Ukrainie. Dobór krajów do porównań międzynarodowych był podyktowany ograniczeniami bazy danych ESPAD [33] oraz uwarunkowaniami polityki wobec alkoholu. Ograniczenia danych z badań ESPAD wynikały z faktu, że jedynie 15 państw dysponowało wszystkimi sześcioma pomiarami, dokonanymi w latach 1995-2015³, wybór państw ograniczał się więc do tej grupy. Wyjątkiem jest tu Francja, którą dołą-

\footnotetext{
${ }^{2}$ Liczba 144357 uczniów odnosi się jedynie do krajów objętych niniejszą analizą.

${ }^{3}$ Były to Czechy, Dania, Finlandia, Irlandia, Islandia, Norwegia, Polska, Portugalia, Słowacja, Słowenia, Szwecja, Ukraina, Węgry, Włochy, Wyspy Owcze.
} 
data gathered for 1995. It was included nonetheless because it is an important reference point for Western Europe, and because of its restrictive regulations regardingalcohol marketing.

The selection of countries reflects the diversity of alcohol policies in Europe [34] and policy models for psychoactive substances [35], as well as differences in drinking styles and amount of alcohol consumed. Sweden's laws reflect a high level of control over alcohol while Denmark's policies reflect a low level of control. Both France and Italy have moderate policies [34]. The Czech Republic is similar to Denmark, they both have liberal alcohol policies and indicators of their youth alcohol consumption are among the highest in Europe. In addition, the Czech Republic and Italy were included in the comparisons as countries with progressive policies: both towards legal as well as illicit psychoactive substances. In contrast, Sweden and France have policies that focus on legal substances, such as alcohol and tobacco, while maintaining very strict policy concerning illicit substances [35]. In this ranking Ukraine is the only country that is not a member of the European Union, and the only country where people predominantly consume spirits rather than other alcoholic beverages. In other countries wine (Denmark, France, Sweden, Italy) or beer (Poland, the Czech Republic) are the most popular [36].

This study analysed the relationship between risk perception and drinking alcohol or abstaining from it during the previous 12 months and previous 30 days before the study. In addition, cases of binge drinking (or lack thereof) were analysed for the previous 30 days $^{4}$. Risk perception associated with alcohol consumption was assessed with the following two questions:

1. How much do you think people risk harming themselves (their health or in other ways) if they drink 1 or 2 drinks almost every day?

2. How much do you think people risk harming themselves (their health or in other ways) if they drink 5 or more drinks every weekend?

Risk perception therefore did not include an assessment of individual student behaviours, rather it pertained to risk perception associated with alcohol in general: as a result of the impact of socio-cultural factors.

${ }^{4}$ Drinking 5 or more portions of alcohol per occasion in the last 30 days was an indicator for binge drinking. czono do analiz, choć nie realizowała pierwszego pomiaru w 1995 roku, lecz stanowi ważny punkt odniesienia w perspektywie krajów Europy Zachodniej oraz $\mathrm{z}$ uwagi na restrykcyjne regulacje dotyczące komunikacji marketingowej alkoholu.

Dobór krajów odzwierciedla zróżnicowanie polityk alkoholowych w Europie [34] oraz modeli polityki wobec substancji psychoaktywnych [35], a także różnice w strukturze i wielkości konsumpcji alkoholu. Szwecja i Dania reprezentują odpowiednio wysoki i niski poziom kontroli w polityce wobec alkoholu, podczas gdy Francja i Włochy umiarkowany [34]. Czechy są z kolei krajem, w którym podobnie jak w Danii prowadzona jest liberalna polityka wobec alkoholu oraz gdzie wskaźniki dotyczące konsumpcji alkoholu wśród młodzieży należą do najwyższych w Europie. Ponadto, Czechy i Włochy zostały uwzględnione $\mathrm{w}$ porównaniach jako kraje o progresywnej polityce - zarówno wobec legalnych, jak i nielegalnych substancji psychoaktywnych. Natomiast Szwecja i Francja należą do państw, w których polityka koncentruje się na substancjach legalnych, takich jak alkohol i tytoń, z jednoczesnym utrzymaniem restrykcyjnego kursu wobec substancji nielegalnych [35]. W tym zestawieniu Ukraina to jedyny kraj niebędący członkiem Unii Europejskiej, a także jedyny kraj, w którym napoje spirytusowe dominują w strukturze spożycia w pozostałych krajach są to wino (Dania, Francja, Szwecja, Włochy) bądź piwo (Polska, Czechy) [36].

$\mathrm{W}$ badaniu analizowany był związek percepcji ryzyka i picia alkoholu bądź abstynencji w okresie ostatnich 12 miesięcy i 30 dni przed badaniem. Ponadto analizowano przypadki upijania się bądź unikania takich zachowań w ciągu ostatnich $30 \mathrm{dni}^{4}$. Źródłem informacji na temat percepcji ryzyka związanego z konsumpcją alkoholu były odpowiedzi na dwa pytania:

1. Jak bardzo, Twoim zdaniem, ludzie ryzykuja, że sobie zaszkodza (zdrowotnie lub w inny sposób), jeśli wypijaja 1 lub 2 drinki prawie codziennie?

2. Jak bardzo, Twoim zdaniem, ludzie ryzykuja, że sobie zaszkodza (zdrowotnie lub w inny sposób), jeśli wypijają 5 drinków lub więcej w czasie każdego weekendu?

Percepcja ryzyka nie odnosiła się więc do oceny indywidualnych zachowań badanych uczniów, lecz do postrzegania ryzyka związanego $\mathrm{z}$ alkoholem w ogóle - jako efektu wpływu czynników społeczno-kulturowych.

\footnotetext{
${ }^{4}$ Wskaźnikiem upijania się było wypijanie jednorazowo 5 lub więcej porcji alkoholu w ciągu ostatnich $30 \mathrm{dni}$.
} 
To avoid problems resulting from imprecise risk assessments, risk perception was subdivided into high risk and low risk. For the purposes of our study, this division also allowed to identify belonging to two risk cultures: low risk perception and high risk perception groups. A high risk perception means that studied persons answered that a given pattern of alcohol consumption is very risky. Regarding low risk perception, respondents rated alcohol consumption as low-risk or no-risk ${ }^{5}$.

The association between risk perception and alcohol consumption was analysed on the basis of aggregated data from all ESPAD measurements and concerning the changes in the years 19952015 and 2011-2015. Risk perception pertained to the two consumption patterns described above: frequent consumption of small amounts of alcohol and binge drinking.

Statistical analyses were carried out using IBM SPSS 21 software. Chi-square tests were used to assess changes in the percentage of young people drinking alcohol and binge-drinking. These tests also assessed changes in alcohol-related risks perception over time as well as the relationship of a high risk and a low risk perception with drinking during the previous 12 months and 30 days and binge drinking. Data from all ESPAD editions were analysed, while separate calculations for 1995 and 2015 were performed for each country. Due to this it was possible to assess changes in the impact of risk perception on alcohol use and binge drinking among young people.

\section{- Results}

\section{Alcohol consumption}

Over the course of 20 years (from 1995 to 2015) the percentage of students who drank alcohol 12 months before the study decreased in all countries except France $(p<0.001-p<0.05)$ (Table I). The biggest decreases took place in Sweden and Ukraine (from $82 \%$ to $52 \%$ and from

\footnotetext{
${ }^{5}$ Students who chose the answer "I don't know" or "moderate risk" were excluded from the analysis. Sample selection influenced its final number; after eliminating the aforementioned answers the sample sizes in the analysed countries were: 1) for analyses of frequent consumption of small amounts of alcohol: $N=12,845$ students in 1995, $N=13,514$ in 2011 and $N=15,693$ in 2015 ; 2) for the binge drinking analysis: $N=14,261$ students in $1995, N=14,205$ in 2011 and $N=17,232$ in 2015 .
}

Aby uniknąć problemów wynikających z nieprecyzyjności ocen ryzyka, percepcja ryzyka została podzielona w badaniu na wysoką i niską. Podział ten pełni również funkcję identyfikacji przynależności do dwóch kultur ryzyka, określonych na potrzeby tego badania: grupy percepcji niskiego i wysokiego ryzyka. Wysoka percepcja ryzyka oznacza, że badani wskazali na odpowiedź, iż dany wzór konsumpcji alkoholu jest bardzo ryzykowny. W przypadku niskiej percepcji ryzyka badani oceniali picie alkoholu jako mało ryzykowne bądź pozbawione ryzyka 5 .

Związek percepcji ryzyka i konsumpcji alkoholu był analizowany na podstawie zagregowanych danych, pochodzących ze wszystkich pomiarów badań ESPAD oraz w odniesieniu do zmian w latach 1995-2015 i 2011-2015. Percepcja ryzyka dotyczyła dwóch wzorów konsumpcji opisanych powyżej: częstego spożywania niewielkich ilości alkoholu i upijania się.

Analizy statystyczne prowadzono z wykorzystaniem oprogramowania IBM SPSS 21. Testami chi-kwadrat posłużono się przy ocenie zmian odsetka młodzieży sięgającej po alkohol i upijającej się oraz zmian percepcji ryzyka związanego $\mathrm{z}$ alkoholem na przestrzeni lat, a także przy ocenie związku wysokiej i niskiej percepcji ryzyka $\mathrm{z}$ faktem sięgania po alkohol w okresie 12 miesięcy i 30 dni oraz upijania się. Analizowano zarówno dane pochodzące ze wszystkich pomiarów badań ESPAD, jak i wykonano oddzielne obliczenia dla lat 1995 i 2015 dla każdego z krajów, dzięki czemu możliwa była ocena zmian we wpływie percepcji ryzyka na sięganie po alkohol i upijanie się wśród młodzieży.

\section{- WYNIKI}

\section{Konsumpcja alkoholu}

$\mathrm{Na}$ przestrzeni 20 lat, od 1995 do 2015 roku, we wszystkich krajach, z wyjątkiem Francji, zmniejszył się odsetek uczniów, którzy pili alkohol w okresie 12 miesięcy przed badaniem $(p<0,001$ $-p<0,05)$ (tab. I). Największy spadek miał miejsce w Szwecji i na Ukrainie (odpowiednio: z 82\%

\footnotetext{
${ }^{5}$ Uczniowie, którzy wybrali odpowiedzi „nie wiem” bądź „umiarkowane ryzyko”, zostali wykluczeni z analizy. Selekcja próby miała wpływ na jej ostateczną liczebność. Po wykluczeniu powyższych ocen liczebność próby wyniosła $\mathrm{w}$ analizowanych krajach: 1) dla analiz częstego spożywania niewielkich ilości alkoholu: $N=12845$ uczniów w 1995 roku, $N=13514$ w 2011 oraz $N=15693$ w 2015; 2) dla analiz upijania się: $N=14261$ uczniów w 1995, $N=14205$ w 2011 oraz $N=17232$ w 2015.
} 
Risk perception and alcohol drinking among young people in seven European countries from 1995 to 2015

Percepcja ryzyka a picie alkoholu wśród młodzieży w siedmiu krajach europejskich w latach 1995-2015

Table I. The percentages of students drinking alcohol in the previous 12 months and changes in the years 1995-2015 and 2011-2015

Tabela I. Odsetki uczniów spożywających alkohol w ciągu 12 miesięcy przed badaniem oraz zmiany w latach 1995-2015 i $2011-2015$

\begin{tabular}{|c|c|c|c|c|c|c|c|c|}
\hline & 1995 & 1999 & 2003 & 2007 & 2011 & 2015 & $\begin{array}{c}\left(\chi^{2}\right) \\
1995-2015\end{array}$ & $\begin{array}{c}\left(\chi^{2}\right) \\
2011-2015\end{array}$ \\
\hline \multirow{2}{*}{$\begin{array}{l}\text { Czech } \\
\text { Republic } \\
\text { Czechy }\end{array}$} & \multirow{2}{*}{$91 \%$} & \multirow{2}{*}{$94 \%$} & \multirow{2}{*}{$95 \%$} & \multirow{2}{*}{$93 \%$} & \multirow{2}{*}{$93 \%$} & \multirow{2}{*}{$90 \%$} & 5.07 & 29.21 \\
\hline & & & & & & & $p<0.05$ & $p<0.001$ \\
\hline \multirow{2}{*}{$\begin{array}{l}\text { Denmark } \\
\text { Dania }\end{array}$} & \multirow{2}{*}{$94 \%$} & \multirow{2}{*}{$96 \%$} & \multirow{2}{*}{$95 \%$} & \multirow{2}{*}{$94 \%$} & \multirow{2}{*}{$92 \%$} & \multirow{2}{*}{$90 \%$} & 26.74 & 9.22 \\
\hline & & & & & & & $p<0.001$ & $p<0.01$ \\
\hline \multirow{2}{*}{$\begin{array}{l}\text { France* } \\
\text { Francja }\end{array}$} & \multirow{2}{*}{ - } & \multirow{2}{*}{$77 \%$} & \multirow{2}{*}{$80 \%$} & \multirow{2}{*}{$82 \%$} & \multirow{2}{*}{$86 \%$} & \multirow{2}{*}{$76 \%$} & \multirow{2}{*}{ - } & 80.35 \\
\hline & & & & & & & & $p<0.001$ \\
\hline \multirow{2}{*}{$\begin{array}{l}\text { Italy } \\
\text { Włochy }\end{array}$} & \multirow{2}{*}{$83 \%$} & \multirow{2}{*}{$75 \%$} & \multirow{2}{*}{$83 \%$} & \multirow{2}{*}{$82 \%$} & \multirow{2}{*}{$80 \%$} & \multirow{2}{*}{$77 \%$} & 22.63 & 11.45 \\
\hline & & & & & & & $p<0.001$ & $p<0.01$ \\
\hline \multirow{2}{*}{$\begin{array}{l}\text { Poland } \\
\text { Polska }\end{array}$} & \multirow{2}{*}{$83 \%$} & \multirow{2}{*}{$84 \%$} & \multirow{2}{*}{$86 \%$} & \multirow{2}{*}{$79 \%$} & \multirow{2}{*}{$79 \%$} & \multirow{2}{*}{$72 \%$} & 275.92 & 106.28 \\
\hline & & & & & & & $p<0.001$ & $p<0.001$ \\
\hline \multirow{2}{*}{$\begin{array}{l}\text { Sweden } \\
\text { Szwecja }\end{array}$} & $82 \%$ & $83 \%$ & $78 \%$ & $72 \%$ & $66 \%$ & $52 \%$ & 611 & 96.30 \\
\hline & $02 \%$ & $05 \%$ & $10 \%$ & $12 \%$ & $00 \%$ & $32 \%$ & $p<0.001$ & $p<0.001$ \\
\hline Ukraine & $81 \%$ & $84 \%$ & $84 \%$ & $84 \%$ & $80 \%$ & $68 \%$ & 175.84 & 82.22 \\
\hline Ukraina & $81 \%$ & $84 \%$ & $84 \%$ & $84 \%$ & $80 \%$ & $68 \%$ & $p<0.001$ & $p<0.001$ \\
\hline
\end{tabular}

*1999-2015

$81 \%$ to $68 \%$ respectively), while the smallest decrease took place in the Czech Republic. Regardless of this trend characteristics and dynamics, the percentage of students who used alcohol in the previous 12 months decreased between 2011 and 2015 in all of the analysed countries $(p<0.001$ $-p<0.01)$. In 1995, the number of Polish teenagers who drank alcohol was much lower than in the Czech Republic and Denmark and almost identical to that of Sweden, Italy and Ukraine. In 2015, the differences between the analysed countries increased and Poland was among the three countries with the lowest percentage of students who drank alcohol.

Between 1995 and 2015 in all countries (except France) the percentage of students who consumed alcohol in the 30 days prior to the study decreased $(p<0.001-p<0.05)$ (Table II). The largest decline (over half) took place in Sweden. Similarly to alcohol consumption in the previous 12 months, the percentage of students who used alcohol in the last 30 days decreased between 2011 and 2015 in all analysed countries (except Denmark) $(p<0.001-p<0,01)$. In 2015 Poland was among the three countries with the lowest percentage of students drinking alcohol in this period. do $52 \%$ i z $81 \%$ do $68 \%$ ), podczas gdy najmniejszy w Czechach. Bez względu na charakter i dynamikę trendu we wszystkich analizowanych krajach odsetek uczniów, którzy sięgali po alkohol, w ciągu ostatnich 12 miesięcy zmniejszył się między 2011 a $2015(p<0,001-p<0,01)$. W 1995 roku liczba polskich nastolatków sięgających po alkohol była zdecydowanie niższa niż w Czechach i w Danii i niemal identyczna jak w Szwecji, we Włoszech i na Ukrainie. W 2015 roku różnice między analizowanymi krajami zwiększyły się, a Polska znalazła się wśród trzech krajów o najniższym odsetku uczniów pijących alkohol.

W latach 1995-2015 we wszystkich krajach, z wyjątkiem Francji, zmniejszył się również odsetek uczniów sięgających po alkohol w okresie 30 dni przed badaniem $(p<0,001-p<0,05)$ (tab. II). Największy spadek, o ponad połowę, miał miejsce w Szwecji. Podobnie jak w przypadku konsumpcji alkoholu w ciągu ostatnich 12 miesięcy, we wszystkich analizowanych krajach (z wyjątkiem Danii) odsetek uczniów, którzy sięgali po alkohol w ciągu ostatnich 30 dni, zmniejszył się między 2011 a 2015 rokiem $(p<0,001-p<0,01)$. W 2015 roku Polska znalazła się wśród trzech krajów o najniższym odsetku uczniów pijących alkohol w tym okresie. 
Table II. The percentages of students drinking alcohol in the previous 30 days and changes in the years 1995-2015 and 2011-2015

Tabela II. Odsetki uczniów spożywających alkohol w ciągu 30 dni przed badaniem oraz zmiany w latach 1995-2015 i 2011-2015

\begin{tabular}{|c|c|c|c|c|c|c|c|c|}
\hline & 1995 & 1999 & 2003 & 2007 & 2011 & 2015 & $\begin{array}{c}\left(\chi^{2}\right) \\
1995-2015\end{array}$ & $\begin{array}{c}\left(\chi^{2}\right) \\
2011-2015\end{array}$ \\
\hline \multirow{2}{*}{$\begin{array}{l}\text { Czech } \\
\text { Republic } \\
\text { Czechy }\end{array}$} & \multirow{2}{*}{$67 \%$} & \multirow{2}{*}{$77 \%$} & \multirow{2}{*}{$77 \%$} & \multirow{2}{*}{$76 \%$} & \multirow{2}{*}{$76 \%$} & \multirow{2}{*}{$70 \%$} & 4.75 & 74.72 \\
\hline & & & & & & & $p<0.05$ & $p<0.001$ \\
\hline \multirow{2}{*}{$\begin{array}{l}\text { Denmark } \\
\text { Dania }\end{array}$} & \multirow{2}{*}{$81 \%$} & \multirow{2}{*}{$85 \%$} & \multirow{2}{*}{$81 \%$} & \multirow{2}{*}{$81 \%$} & \multirow{2}{*}{$76 \%$} & \multirow{2}{*}{$74 \%$} & 25.56 & \multirow{2}{*}{-} \\
\hline & & & & & & & $p<0.001$ & \\
\hline \multirow{2}{*}{$\begin{array}{l}\text { France* } \\
\text { Francja }\end{array}$} & \multirow{2}{*}{-} & \multirow{2}{*}{$46 \%$} & \multirow{2}{*}{$57 \%$} & \multirow{2}{*}{$66 \%$} & \multirow{2}{*}{$68 \%$} & \multirow{2}{*}{$57 \%$} & 56.47 & 68.60 \\
\hline & & & & & & & $p<0.001^{*}$ & $p<0.001$ \\
\hline \multirow{2}{*}{$\begin{array}{l}\text { Italy } \\
\text { Włochy }\end{array}$} & \multirow{2}{*}{$65 \%$} & \multirow{2}{*}{$54 \%$} & \multirow{2}{*}{$65 \%$} & \multirow{2}{*}{$65 \%$} & \multirow{2}{*}{$63 \%$} & \multirow{2}{*}{$57 \%$} & 28.46 & 33.37 \\
\hline & & & & & & & $p<0.001$ & $p<0.001$ \\
\hline \multirow{2}{*}{$\begin{array}{l}\text { Poland } \\
\text { Polska }\end{array}$} & \multirow{2}{*}{$56 \%$} & \multirow{2}{*}{$61 \%$} & \multirow{2}{*}{$67 \%$} & \multirow{2}{*}{$58 \%$} & \multirow{2}{*}{$58 \%$} & \multirow{2}{*}{$49 \%$} & 103.32 & 150.83 \\
\hline & & & & & & & $p<0.001$ & $p<0.001$ \\
\hline \multirow{2}{*}{$\begin{array}{l}\text { Sweden } \\
\text { Szwecja }\end{array}$} & $55 \%$ & $56 \%$ & $51 \%$ & $46 \%$ & $39 \%$ & $27 \%$ & 495.42 & 84.02 \\
\hline & $55 \%$ & $56 \%$ & $31 \%$ & $46 \%$ & $39 \%$ & $21 \%$ & $p<0.001$ & $p<0.001$ \\
\hline Ukraine & $57 \%$ & $61 \%$ & $58 \%$ & $62 \%$ & $55 \%$ & $39 \%$ & 225.50 & 121.61 \\
\hline Ukraina & & & & & & & $p<0.001$ & $p<0.001$ \\
\hline
\end{tabular}

*1999-2015

Trends in binge drinking (consuming more than 5 portions of alcohol per occasion during the previous 30 days) between 1995 and 2015 were less unambiguous (Table III). At that time, the proportion of students who binge drank was reduced in Denmark, Sweden and Ukraine $(p<0.001-$ $p<0.01)$ while increasing in the Czech Republic and Italy $(p<0.05-p<0.01)$. Poland noted a sharp increase in the second half of the 1990s, followed by a decrease and return to 1995 level. The changes between 2011 and 2015 turned out to be statistically significant only in case of Poland, the Czech Republic, France and Sweden $(p<0.001)$. In other countries, the percentage of binge drinkers remained almost the same: with the highest rate (more than half of students) in Denmark.

Risk perception of frequent consumption of small amounts of alcohol

Over the course of the 20 years between 1995 and $2015^{6}$, the percentage of students who assessed frequent consumption of small amounts of alcohol as no-risk or low-risk decreased in Denmark,

\footnotetext{
${ }^{6}$ In France's case, due to the lack of the first ESPAD measurement in 1995, the trend from period 1999-2015 was analysed $(p<0.001)$.
}

Trendy w upijaniu się (spożywanie więcej niż 5 porcji alkoholu przy jednej okazji w ciągu ostatnich 30 dni) w latach 1995-2015 miały mniej jednoznaczny charakter (tab. III). W tym czasie liczba uczniów, którzy się upijali, uległa ograniczeniu w Danii, Szwecji oraz na Ukrainie $(p<0,001$ $-p<0,01)$, wzrosła w Czechach i we Włoszech $(p<0,05-p<0,01)$, podczas gdy w Polsce, po sporym wzroście $\mathrm{w}$ drugiej połowie lat 90 ., nastąpił spadek i powrót do poziomu z 1995 roku. Zmiany w latach 2011-2015 okazały się istotne statystycznie jedynie w przypadku Polski, Czech, Francji i Szwecji $(p<0,001)$. W pozostałych krajach odsetek uczniów upijających się utrzymał się na niemal identycznym poziomie - z najwyższym, przekraczającym ponad połowę uczniów, w przypadku Danii.

\section{Percepcja ryzyka częstego spożywania niewielkich ilości alkoholu}

W czasie 20 lat, między 1995 a 2015 rokiem $^{6}$, w Danii, Francji, we Włoszech oraz na Ukrainie zmniejszał się odsetek uczniów, którzy oceniali częstą konsumpcję niewielkich ilości alkoholu

\footnotetext{
${ }^{6} \mathrm{~W}$ przypadku Francji, z uwagi na brak pierwszego pomiaru ESPAD w 1995 roku, analizowany był trend z okresu 1999-2015 $(p<0,001)$.
} 
Table III. The percentages of students who engaged in binge drinking in the previous 30 days and changes in the years 1995-2015 and 2011-2015

Tabela III. Odsetki uczniów, którzy upijali się w ciągu 30 dni przed badaniem oraz zmiany w latach 1995-2015 i $2011-2015$

\begin{tabular}{|c|c|c|c|c|c|c|c|c|}
\hline & 1995 & 1999 & 2003 & 2007 & 2011 & 2015 & $\begin{array}{c}\left(\chi^{2}\right) \\
1995-2015\end{array}$ & $\begin{array}{c}\left(\chi^{2}\right) \\
2011-2015\end{array}$ \\
\hline \multirow{2}{*}{$\begin{array}{l}\text { Czech } \\
\text { Republic } \\
\text { Czechy }\end{array}$} & \multirow{2}{*}{$38 \%$} & \multirow{2}{*}{$43 \%$} & \multirow{2}{*}{$47 \%$} & \multirow{2}{*}{$52 \%$} & \multirow{2}{*}{$54 \%$} & \multirow{2}{*}{$41 \%$} & 6.23 & 105.98 \\
\hline & & & & & & & $p<0.05$ & $p<0.001$ \\
\hline \multirow{2}{*}{$\begin{array}{l}\text { Denmark } \\
\text { Dania }\end{array}$} & \multirow{2}{*}{$61 \%$} & \multirow{2}{*}{$64 \%$} & \multirow{2}{*}{$60 \%$} & \multirow{2}{*}{$60 \%$} & \multirow{2}{*}{$57 \%$} & \multirow{2}{*}{$57 \%$} & 7.49 & \multirow{2}{*}{ - } \\
\hline & & & & & & & $p<0.01$ & \\
\hline \multirow{2}{*}{$\begin{array}{l}\text { France } \\
\text { Francja }\end{array}$} & \multirow{2}{*}{ - } & \multirow{2}{*}{$33 \%$} & \multirow{2}{*}{$29 \%$} & \multirow{2}{*}{$45 \%$} & \multirow{2}{*}{$43 \%$} & \multirow{2}{*}{$33 \%$} & \multirow{2}{*}{ - } & 49.00 \\
\hline & & & & & & & & $p<0.001$ \\
\hline \multirow{2}{*}{$\begin{array}{l}\text { Italy } \\
\text { Włochy }\end{array}$} & \multirow{2}{*}{$30 \%$} & \multirow{2}{*}{$27 \%$} & \multirow{2}{*}{$33 \%$} & \multirow{2}{*}{$40 \%$} & \multirow{2}{*}{$35 \%$} & \multirow{2}{*}{$35 \%$} & 10.17 & \multirow{2}{*}{-} \\
\hline & & & & & & & $p<0.01$ & \\
\hline \multirow{2}{*}{$\begin{array}{l}\text { Poland } \\
\text { Polska }\end{array}$} & \multirow{2}{*}{$35 \%$} & \multirow{2}{*}{$47 \%$} & \multirow{2}{*}{$42 \%$} & \multirow{2}{*}{$39 \%$} & \multirow{2}{*}{$38 \%$} & $35 \%$ & - & 22.85 \\
\hline & & & & & & & & $p<0.001$ \\
\hline Sweden & $41 \%$ & 13\%\% & $37 \%$ & $38 \%$ & $32 \%$ & $23 \%$ & 226.08 & 51.36 \\
\hline Szwecja & & & & & & & $p<0.001$ & $p<0.001$ \\
\hline Ukraine & $45 \%$ & $36 \%$ & $37 \%$ & $36 \%$ & $30 \%$ & $30 \%$ & 175.90 & - \\
\hline Ukraina & $45 \%$ & $50 \%$ & שו & $50 \%$ & $50 \%$ & 年 & $p<0.001$ & \\
\hline
\end{tabular}

*1999-2015

France, Italy and Ukraine $(p<0.001)$ (Table IV). However student's perceptions of high-risk increased in Poland, the Czech Republic and Sweden $(p<0.001)$.

The year 2011 marked a turning point for countries in which was noted decrease of the percentages of students assessing low- or no-risk pertaining to moderate alcohol consumption. Between 2011 and 2015, an upward trend was clearly visible in all studied countries $(p<0.001-p<0.05)$.

A high risk perception of frequent consumption of small amounts of alcohol corresponded largely with the trend of low risk ratings (Table V). Between 1995 and 2015, the number of students who assessed this style of consumption as highrisk consistently decreased in Poland, the Czech Republic and Sweden $(p<0.001)$. In Ukraine and Italy, however, the number of students for whom frequently drinking small amounts of alcohol was perceived as highly risky $(p<0.001)$ increased. In Italy the increase was 2.5 times greater. Compared to other countries, no statistically significant changes were noted in Denmark and France. Between 2011 and 2015, in all countries, besides Poland, the percentage of students who perceived frequently drinking small amounts jako pozbawioną ryzyka albo mało ryzykowną $(p<0,001)$ (tab. IV). Zmiany w przeciwnym kierunku nastąpiły w Polsce, Czechach i w Szwecji $(p<0,001)$.

Rok 2011 był punktem zwrotnym dla krajów, w których notowano spadki odsetka ocen niskiego bądź braku ryzyka związanego z umiarkowaną konsumpcją alkoholu. W latach 2011-2015 we wszystkich krajach wyraźnie zarysował się trend wzrostowy $(p<0,001-p<0,05)$.

Wysoka percepcja ryzyka dotyczącego częstego spożywania niewielkich ilości alkoholu w dużej mierze korespondowała $\mathrm{z}$ trendem ocen niskiego ryzyka (tab. V). W latach 1995-2015 w Polsce, Czechach oraz Szwecji konsekwentnie malała liczba uczniów oceniających ten wzór konsumpcji jako wysoce ryzykowny $(p<0,001)$. Na Ukrainie i we Włoszech wzrosła jednak liczba uczniów, dla których częste picie małych ilości alkoholu było wysoce ryzykowne $(p<0,001)$, przy czym we Włoszech wzrost ten był aż 2,5-krotny. Na tle pozostałych państw wyróżniała się sytuacja w Danii oraz we Francji, gdzie nie odnotowano żadnych istotnych statystycznie zmian w tym zakresie. W latach 2011-2015 we wszystkich krajach, z wyjątkiem Polski, malał odsetek uczniów, którzy postrzegali 
Table IV. The percentages of students who consider frequently drinking small amounts of alcohol as a low-risk or no-risk behaviour and changes in the years 1995-2015 and 2011-2015

Tabela IV. Odsetki uczniów oceniających częste spożywanie niewielkich ilości alkoholu jako zachowanie o niskim stopniu ryzyka bądź pozbawione ryzyka oraz zmiany w latach 1995-2015 i 2011-2015

\begin{tabular}{|c|c|c|c|c|c|c|c|c|}
\hline & 1995 & 1999 & 2003 & 2007 & 2011 & 2015 & $\begin{array}{c}\left(\chi^{2}\right) \\
1995-2015\end{array}$ & $\begin{array}{c}\left(\chi^{2}\right) \\
2011-2015\end{array}$ \\
\hline \multirow{2}{*}{$\begin{array}{l}\text { Czech } \\
\text { Republic } \\
\text { Czechy }\end{array}$} & \multirow{2}{*}{$34 \%$} & \multirow{2}{*}{$41 \%$} & \multirow{2}{*}{$45 \%$} & \multirow{2}{*}{$46 \%$} & \multirow{2}{*}{$47 \%$} & \multirow{2}{*}{$51 \%$} & 167.62 & 10.47 \\
\hline & & & & & & & $p<0.001$ & $p<0.01$ \\
\hline \multirow{2}{*}{$\begin{array}{l}\text { Denmark } \\
\text { Dania }\end{array}$} & \multirow{2}{*}{$40 \%$} & \multirow{2}{*}{$38 \%$} & \multirow{2}{*}{$42 \%$} & \multirow{2}{*}{$27 \%$} & \multirow{2}{*}{$25 \%$} & \multirow{2}{*}{$33 \%$} & 15.64 & 27.66 \\
\hline & & & & & & & $p<0.001$ & $p<0.001$ \\
\hline \multirow{2}{*}{$\begin{array}{l}\text { France* } \\
\text { Francja }\end{array}$} & \multirow{2}{*}{ - } & \multirow{2}{*}{$49 \%$} & \multirow{2}{*}{$40 \%$} & \multirow{2}{*}{$38 \%$} & \multirow{2}{*}{$32 \%$} & \multirow{2}{*}{$43 \%$} & 20.04 & 65.10 \\
\hline & & & & & & & $p<0.001^{*}$ & $p<0.001$ \\
\hline \multirow{2}{*}{$\begin{array}{l}\text { Italy } \\
\text { Włochy }\end{array}$} & \multirow{2}{*}{$52 \%$} & \multirow{2}{*}{$46 \%$} & \multirow{2}{*}{$34 \%$} & \multirow{2}{*}{$33 \%$} & \multirow{2}{*}{$17 \%$} & \multirow{2}{*}{$22 \%$} & 419.69 & 30.61 \\
\hline & & & & & & & $p<0.001$ & $p<0.001$ \\
\hline \multirow{2}{*}{$\begin{array}{l}\text { Poland } \\
\text { Polska }\end{array}$} & \multirow{2}{*}{$18 \%$} & \multirow{2}{*}{$28 \%$} & \multirow{2}{*}{$30 \%$} & \multirow{2}{*}{$27 \%$} & \multirow{2}{*}{$29 \%$} & \multirow{2}{*}{$30 \%$} & 358.44 & 5.08 \\
\hline & & & & & & & $p<0.001$ & $p<0.05$ \\
\hline \multirow{2}{*}{$\begin{array}{l}\text { Sweden } \\
\text { Szwecja }\end{array}$} & \multirow{2}{*}{$18 \%$} & 100 & 210 & 210 & \%רכ & 3 & 101.81 & 43.03 \\
\hline & & $10 \%$ & $21 \%$ & 2110 & 2210 & (2010 & $p<0.001$ & $p<0.001$ \\
\hline Ukraine & $24 \%$ & $20 \%$ & $17 \%$ & $22 \%$ & $11 \%$ & $16 \%$ & 59.04 & 18.37 \\
\hline Ukraina & & & & & & & $p<0.001$ & $p<0.001$ \\
\hline
\end{tabular}

*1999-2015

Table V. The percentages of students who consider frequently drinking small amounts of alcohol as a high-risk behaviour and changes in the years 1995-2015 and 2011-2015

Tabela V. Odsetki uczniów oceniających częste spożywanie niewielkich ilości alkoholu jako zachowanie o wysokim stopniu ryzyka oraz zmiany w latach 1995-2015 i 2011-2015

\begin{tabular}{|c|c|c|c|c|c|c|c|c|}
\hline & 1995 & 1999 & 2003 & 2007 & 2011 & 2015 & $\begin{array}{c}\left(\chi^{2}\right) \\
1995-2015\end{array}$ & $\begin{array}{c}\left(\chi^{2}\right) \\
2011-2015\end{array}$ \\
\hline \multirow{2}{*}{$\begin{array}{l}\text { Czech } \\
\text { Republic } \\
\text { Czechy }\end{array}$} & \multirow{2}{*}{$26 \%$} & \multirow{2}{*}{$17 \%$} & \multirow{2}{*}{$16 \%$} & \multirow{2}{*}{$14 \%$} & \multirow{2}{*}{$13 \%$} & \multirow{2}{*}{$11 \%$} & 204.71 & 6.76 \\
\hline & & & & & & & $p<0.001$ & $p<0.01$ \\
\hline \multirow{2}{*}{$\begin{array}{l}\text { Denmark } \\
\text { Dania }\end{array}$} & \multirow{2}{*}{$16 \%$} & \multirow{2}{*}{$18 \%$} & \multirow{2}{*}{$14 \%$} & \multirow{2}{*}{$21 \%$} & \multirow{2}{*}{$25 \%$} & \multirow{2}{*}{$17 \%$} & \multirow{2}{*}{-} & 32.51 \\
\hline & & & & & & & & $p<0.001$ \\
\hline \multirow{2}{*}{$\begin{array}{l}\text { France* } \\
\text { Francja }\end{array}$} & \multirow{2}{*}{-} & \multirow{2}{*}{$15 \%$} & \multirow{2}{*}{$19 \%$} & \multirow{2}{*}{$19 \%$} & \multirow{2}{*}{$24 \%$} & \multirow{2}{*}{$13 \%$} & \multirow{2}{*}{-} & 94.38 \\
\hline & & & & & & & & $p<0.001$ \\
\hline \multirow{2}{*}{$\begin{array}{l}\text { Italy } \\
\text { Włochy }\end{array}$} & \multirow{2}{*}{$13 \%$} & \multirow{2}{*}{$12 \%$} & \multirow{2}{*}{$19 \%$} & \multirow{2}{*}{$20 \%$} & \multirow{2}{*}{$37 \%$} & \multirow{2}{*}{$34 \%$} & 221.00 & 10.73 \\
\hline & & & & & & & $p<0.001$ & $p<0.01$ \\
\hline \multirow{2}{*}{$\begin{array}{l}\text { Poland } \\
\text { Polska }\end{array}$} & \multirow{2}{*}{$38 \%$} & \multirow{2}{*}{$33 \%$} & \multirow{2}{*}{$32 \%$} & \multirow{2}{*}{$28 \%$} & \multirow{2}{*}{$28 \%$} & \multirow{2}{*}{$27 \%$} & 196.52 & - \\
\hline & & & & & & & $p<0.001$ & - \\
\hline & & & & & & $21 \%$ & 270.60 & 50.50 \\
\hline Szwecja & $42 \%$ & $42 \%$ & $34 \%$ & $33 \%$ & $30 \%$ & $21 \%$ & $p<0.001$ & $p<0.001$ \\
\hline Ukraine & $37 \%$ & $31 \%$ & $37 \%$ & $30 \%$ & $55 \%$ & $43 \%$ & 36.57 & 56.01 \\
\hline Ukraina & 政 & 年 & סיזני & 5010 & סדנדו & 更 & $p<0.001$ & $p<0.001$ \\
\hline
\end{tabular}

*1999-2015 
Table VI. The percentages of students who consider binge drinking as a low-risk or no-risk behaviour and changes in the years 1995-2015 and 2011-2015

Tabela VI. Odsetki uczniów oceniających upijanie się jako zachowanie o niskim stopniu ryzyka bądź pozbawione ryzyka oraz zmiany w latach 1995-2015 i 2011-2015

\begin{tabular}{|c|c|c|c|c|c|c|c|c|}
\hline & 1995 & 1999 & 2003 & 2007 & 2011 & 2015 & $\begin{array}{c}\left(\chi^{2}\right) \\
1995-2015\end{array}$ & $\begin{array}{c}\left(\chi^{2}\right) \\
2011-2015\end{array}$ \\
\hline $\begin{array}{l}\text { Czech } \\
\text { Republic } \\
\text { Czechy }\end{array}$ & $18 \%$ & $24 \%$ & $28 \%$ & $22 \%$ & $19 \%$ & $19 \%$ & - & - \\
\hline \multirow{2}{*}{$\begin{array}{l}\text { Denmark } \\
\text { Dania }\end{array}$} & \multirow{2}{*}{$48 \%$} & \multirow{2}{*}{$44 \%$} & \multirow{2}{*}{$33 \%$} & \multirow{2}{*}{$30 \%$} & \multirow{2}{*}{$23 \%$} & \multirow{2}{*}{$19 \%$} & 352.18 & 12.05 \\
\hline & & & & & & & $p<0.001$ & $p<0.01$ \\
\hline \multirow{2}{*}{$\begin{array}{l}\text { France* } \\
\text { Francja }\end{array}$} & \multirow{2}{*}{-} & \multirow{2}{*}{-} & \multirow{2}{*}{$14 \%$} & \multirow{2}{*}{$19 \%$} & \multirow{2}{*}{$15 \%$} & \multirow{2}{*}{$16 \%$} & 5.13 & \multirow{2}{*}{-} \\
\hline & & & & & & & $p<0.05^{*}$ & \\
\hline \multirow{2}{*}{$\begin{array}{l}\text { Italy } \\
\text { Włochy }\end{array}$} & \multirow{2}{*}{$24 \%$} & \multirow{2}{*}{$21 \%$} & \multirow{2}{*}{$15 \%$} & \multirow{2}{*}{$16 \%$} & \multirow{2}{*}{$13 \%$} & \multirow{2}{*}{$13 \%$} & 80.51 & \multirow{2}{*}{-} \\
\hline & & & & & & & $p<0.001$ & \\
\hline \multirow{2}{*}{$\begin{array}{l}\text { Poland } \\
\text { Polska }\end{array}$} & \multirow{2}{*}{$16 \%$} & \multirow{2}{*}{$17 \%$} & \multirow{2}{*}{$18 \%$} & \multirow{2}{*}{$14 \%$} & \multirow{2}{*}{$17 \%$} & \multirow{2}{*}{$15 \%$} & \multirow{2}{*}{-} & 11.12 \\
\hline & & & & & & & & $p<0.01$ \\
\hline \multirow{2}{*}{$\begin{array}{l}\text { Sweden } \\
\text { Szwecja }\end{array}$} & \multirow{2}{*}{$16 \%$} & \multirow{2}{*}{$15 \%$} & \multirow{2}{*}{$14 \%$} & \multirow{2}{*}{$16 \%$} & \multirow{2}{*}{$13 \%$} & \multirow{2}{*}{$16 \%$} & _- & 11.12 \\
\hline & & & & & & & & $p<0.01$ \\
\hline Ukraine & $11 \%$ & $14 \%$ & $12 \%$ & $16 \%$ & $8 \%$ & $8 \%$ & 17.49 & _ \\
\hline Ukraina & $11 \%$ & $14 \%$ & $12 \%$ & $10 \%$ & $0 \%$ & $0 \%$ & $p<0.001$ & \\
\hline
\end{tabular}

*2003-2015

Table VII. The percentages of students who consider binge drinking as a high-risk behaviour and changes in the years 1995-2015 and 2011-2015

Tabela VII. Odsetki uczniów oceniających upijanie się jako zachowanie o wysokim stopniu ryzyka oraz zmiany w latach 1995-2015 i 2011-2015

\begin{tabular}{|c|c|c|c|c|c|c|c|c|}
\hline & 1995 & 1999 & 2003 & 2007 & 2011 & 2015 & $\begin{array}{c}\left(\chi^{2}\right) \\
1995-2015\end{array}$ & $\begin{array}{c}\left(\chi^{2}\right) \\
2011-2015\end{array}$ \\
\hline \multirow{2}{*}{$\begin{array}{l}\text { Czech } \\
\text { Republic } \\
\text { Czechy }\end{array}$} & \multirow[b]{2}{*}{$39 \%$} & \multirow[b]{2}{*}{$28 \%$} & \multirow[b]{2}{*}{$25 \%$} & \multirow[b]{2}{*}{$37 \%$} & \multirow[b]{2}{*}{$38 \%$} & \multirow[b]{2}{*}{$36 \%$} & 4.71 & \multirow[b]{2}{*}{-} \\
\hline & & & & & & & $p<0.05$ & \\
\hline \multirow{2}{*}{$\begin{array}{l}\text { Denmark } \\
\text { Dania }\end{array}$} & \multirow{2}{*}{$13 \%$} & \multirow{2}{*}{$17 \%$} & \multirow{2}{*}{$26 \%$} & \multirow{2}{*}{$26 \%$} & \multirow{2}{*}{$33 \%$} & \multirow{2}{*}{$38 \%$} & 348.14 & 10.91 \\
\hline & & & & & & & $p<0.001$ & $p<0.01$ \\
\hline \multirow{2}{*}{$\begin{array}{l}\text { France* } \\
\text { Francja }\end{array}$} & \multirow{2}{*}{-} & \multirow{2}{*}{-} & \multirow{2}{*}{$51 \%$} & \multirow{2}{*}{$41 \%$} & \multirow{2}{*}{$41 \%$} & \multirow{2}{*}{$47 \%$} & 6.66 & 18.12 \\
\hline & & & & & & & $p<0.05^{*}$ & $p<0.001$ \\
\hline \multirow{2}{*}{$\begin{array}{l}\text { Italy } \\
\text { Włochy }\end{array}$} & \multirow{2}{*}{$32 \%$} & \multirow{2}{*}{$34 \%$} & \multirow{2}{*}{$44 \%$} & \multirow{2}{*}{$45 \%$} & \multirow{2}{*}{$45 \%$} & \multirow{2}{*}{$54 \%$} & 211.41 & 79.25 \\
\hline & & & & & & & $p<0.001$ & $p<0.001$ \\
\hline \multirow{2}{*}{$\begin{array}{l}\text { Poland } \\
\text { Polska }\end{array}$} & \multirow{2}{*}{$41 \%$} & \multirow{2}{*}{$46 \%$} & \multirow{2}{*}{$48 \%$} & \multirow{2}{*}{$46 \%$} & \multirow{2}{*}{$42 \%$} & \multirow{2}{*}{$46 \%$} & 97.70 & 20.12 \\
\hline & & & & & & & $p<0.001$ & $p<0.001$ \\
\hline \multirow{2}{*}{$\begin{array}{l}\text { Sweden } \\
\text { Szwecja }\end{array}$} & $45 \%$ & $44 \%$ & $46 \%$ & $46 \%$ & $49 \%$ & $45 \%$ & _ & 4.51 \\
\hline & & $44 \%$ & $40 \%$ & $40 \%$ & $49 \%$ & $45 \%$ & - & $p<0.05$ \\
\hline Ukraine & $58 \%$ & $40 \%$ & $45 \%$ & $41 \%$ & $62 \%$ & $62 \%$ & 28.10 & - \\
\hline Ukraina & $58 \%$ & $40 \%$ & $45 \%$ & $41 \%$ & $02 \%$ & $02 \%$ & $p<0.001$ & - \\
\hline
\end{tabular}

*2003-2015 
Table VIII. Low and high risk perception of frequently drinking small amounts of alcohol and abstinence in the previous 12 months, 30 days and binge drinking (all years) $\left(\chi^{2}\right)$

Tabela VIII. Związek niskiej i wysokiej percepcji ryzyka częstego spożywania niewielkich ilości alkoholu i abstynencji w ciągu 12 miesięcy i 30 dni przed badaniem oraz upijania się (wszystkie lata) $\left(\chi^{2}\right)$

\begin{tabular}{|c|c|c|c|c|c|c|c|c|c|c|}
\hline & & \multicolumn{9}{|c|}{ Low risk/Niska ocena ryzyka } \\
\hline & & \multicolumn{3}{|c|}{12 months/miesięcy } & \multicolumn{3}{|c|}{30 days/dni } & \multicolumn{3}{|c|}{ Binge drinking/Upijanie się } \\
\hline & & $\begin{array}{l}\text { Low risk/ } \\
\text { Niskie } \\
\text { ryzyko }\end{array}$ & $\begin{array}{l}\text { Other } \\
\text { risks/ } \\
\text { Inne } \\
\text { oceny } \\
\text { ryzyka }\end{array}$ & $\chi^{2}$ & $\begin{array}{l}\text { Low risk/ } \\
\text { Niskie } \\
\text { ryzyko }\end{array}$ & $\begin{array}{l}\text { Other } \\
\text { risks/ } \\
\text { Inne } \\
\text { oceny } \\
\text { ryzyka }\end{array}$ & $\chi^{2}$ & $\begin{array}{l}\text { Low } \\
\text { risk/ } \\
\text { Niskie } \\
\text { ryzyko }\end{array}$ & $\begin{array}{l}\text { Other } \\
\text { risks/ } \\
\text { Inne } \\
\text { oceny } \\
\text { ryzyka }\end{array}$ & $\chi^{2}$ \\
\hline \multirow{4}{*}{$\begin{array}{l}\text { Czech } \\
\text { Republic } \\
\text { Czechy }\end{array}$} & \multirow{2}{*}{$\begin{array}{c}\text { Drinkers } \\
\text { Pijący }\end{array}$} & 8332 & 10422 & \multirow{2}{*}{28.4} & 7009 & 8098 & \multirow{2}{*}{150.19} & 4673 & 4701 & \multirow{2}{*}{250.49} \\
\hline & & $44 \%$ & $56 \%$ & & $46 \%$ & $54 \%$ & & $50 \%$ & $50 \%$ & \\
\hline & \multirow{2}{*}{$\begin{array}{l}\text { Abstainers } \\
\text { Abstynenci }\end{array}$} & 534 & 902 & \multirow{2}{*}{$p<0.001$} & 1857 & 3226 & \multirow{2}{*}{$p<0.001$} & 4193 & 6623 & \multirow{2}{*}{$p<0.001$} \\
\hline & & $37 \%$ & $63 \%$ & & $37 \%$ & $64 \%$ & & $39 \%$ & $61 \%$ & \\
\hline \multirow{4}{*}{$\begin{array}{l}\text { Denmark } \\
\text { Dania }\end{array}$} & \multirow{2}{*}{$\begin{array}{l}\text { Drinkers } \\
\text { Pijący }\end{array}$} & 3621 & 6676 & \multirow{2}{*}{15.49} & 3163 & 5563 & \multirow{2}{*}{44.69} & 2473 & 4062 & \multirow{2}{*}{70.18} \\
\hline & & $35 \%$ & $65 \%$ & & $36 \%$ & $64 \%$ & & $38 \%$ & $62 \%$ & \\
\hline & \multirow{2}{*}{$\begin{array}{l}\text { Abstainers } \\
\text { Abstynenci }\end{array}$} & 194 & 503 & \multirow{2}{*}{$p<0.001$} & 652 & 1616 & \multirow{2}{*}{$p<0.001$} & 1342 & 3117 & \multirow{2}{*}{$p<0.001$} \\
\hline & & $28 \%$ & $72 \%$ & & $29 \%$ & $71 \%$ & & $30 \%$ & $70 \%$ & \\
\hline \multirow{4}{*}{$\begin{array}{l}\text { France } \\
\text { Francja }\end{array}$} & \multirow{2}{*}{$\begin{array}{c}\text { Drinkers } \\
\text { Pijący }\end{array}$} & 4236 & 5977 & \multirow{2}{*}{68.84} & 3235 & 4294 & \multirow{2}{*}{82.74} & 2164 & 2528 & \multirow{2}{*}{128.46} \\
\hline & & $42 \%$ & $59 \%$ & & $43 \%$ & $57 \%$ & & $46 \%$ & $54 \%$ & \\
\hline & \multirow{2}{*}{$\begin{array}{l}\text { Abstainers } \\
\text { Abstynenci }\end{array}$} & 822 & 1710 & $n$ & 1823 & 3393 & $n<0 \cap 01$ & 2894 & 5159 & $n<0001$ \\
\hline & & $33 \%$ & $68 \%$ & $p<0.001$ & $35 \%$ & $65 \%$ & $p<0.001$ & $36 \%$ & $64 \%$ & $p<0.001$ \\
\hline & Drinkers & 7591 & 15776 & 11 & 6164 & 11908 & 20 & 3772 & 6488 & 24066 \\
\hline & Pijący & $33 \%$ & $68 \%$ & 111.39 & $34 \%$ & $66 \%$ & 200.2 & $37 \%$ & $63 \%$ & 240.06 \\
\hline Włochy & Abstainers & 1479 & 4359 & & 2906 & 8227 & & 5298 & 13647 & \\
\hline & Abstynenci & $25 \%$ & $75 \%$ & $p<0.001$ & $26 \%$ & $74 \%$ & $p<0.001$ & $28 \%$ & $72 \%$ & 0.001 \\
\hline & Drinkers & 8219 & 20490 & 23308 & 6369 & 14061 & 15520 & 4816 & 8978 & 70616 \\
\hline Poland & Pijący & $29 \%$ & $71 \%$ & 233.08 & $31 \%$ & $69 \%$ & 433.29 & $35 \%$ & $65 \%$ & 140.10 \\
\hline Polska & Abstainers & 1521 & 6114 & & 3371 & 12543 & & 4924 & 17626 & $p<0.001$ \\
\hline & Abstynenci & $20 \%$ & $80 \%$ & 0.001 & $21 \%$ & $79 \%$ & .001 & $22 \%$ & $78 \%$ & $p<0.001$ \\
\hline & Drinkers & 2910 & 10448 & 1 & 1924 & 6591 & 2153 & 1578 & 5039 & 4718 \\
\hline Sweden & Pijący & $22 \%$ & $78 \%$ & 14.16 & $23 \%$ & $77 \%$ & 21.33 & $24 \%$ & $76 \%$ & \\
\hline Szwecja & Abstainers & 940 & 3951 & & 1926 & 7808 & & 2272 & 9360 & 001 \\
\hline & Abstynenci & $19 \%$ & $81 \%$ & 001 & $20 \%$ & $80 \%$ & 01 & $20 \%$ & $81 \%$ & 0.001 \\
\hline & Drinkers & 3403 & 13382 & 65.94 & 2551 & 9023 & 136.53 & 1997 & 5811 & 328.52 \\
\hline Ukraine & Pijący & $20 \%$ & $80 \%$ & 63.94 & $22 \%$ & $78 \%$ & 136.33 & $26 \%$ & $74 \%$ & 328.52 \\
\hline Ukraina & Abstainers & 572 & 3346 & $<0001$ & 1424 & 7705 & $<0001$ & 1978 & 10917 & \\
\hline & & $15 \%$ & $85 \%$ & $p<0.001$ & $16 \%$ & $84 \%$ & $p<0.001$ & $15 \%$ & $85 \%$ & .0 .001 \\
\hline
\end{tabular}

of alcohol as a high-risk behaviour $(p<0.01)$ decreased.

Risk perception of binge drinking

Compared to the risk assessment of frequent consumption of small amounts of alcohol, binge drinking risk perception was more diversified (Table VI). Between 1995 and 2015 there was a drop in the number of students assessing częste picie niewielkich ilości alkoholu jako zachowanie związane z wysokim ryzykiem $(p<0,01)$.

\section{Percepcja ryzyka upijania się}

W porównaniu $\mathrm{z}$ ocenami ryzyka częstego spożywania niewielkich ilości alkoholu percepcja ryzyka upijania się była bardziej zróżnicowana (tab. VI). W latach 1995-2015 w Danii, we Włoszech oraz na Ukrainie nastąpił spadek liczby uczniów 
Table VIII. Continued

Tabela VIII. Ciąg dalszy

\begin{tabular}{|c|c|c|c|c|c|c|c|c|c|c|}
\hline & & \multicolumn{9}{|c|}{ High risk/Wysoka ocena ryzyka } \\
\hline & & \multicolumn{3}{|c|}{12 months/miesięcy } & \multicolumn{3}{|c|}{30 days/dni } & \multicolumn{3}{|c|}{ Binge drinking/Upijanie się } \\
\hline & & $\begin{array}{l}\text { High risk/ } \\
\text { Wysokie } \\
\text { ryzyko }\end{array}$ & $\begin{array}{l}\text { Other } \\
\text { risks/ } \\
\text { Inne } \\
\text { oceny } \\
\text { ryzyka }\end{array}$ & $\chi^{2}$ & $\begin{array}{c}\text { High } \\
\text { risk/ } \\
\text { Wysokie } \\
\text { ryzyko }\end{array}$ & $\begin{array}{l}\text { Other } \\
\text { risks/ } \\
\text { Inne } \\
\text { oceny } \\
\text { ryzyka }\end{array}$ & $\chi^{2}$ & $\begin{array}{c}\text { High risk/ } \\
\text { Wysokie } \\
\text { ryzyko }\end{array}$ & $\begin{array}{l}\text { Other } \\
\text { risks/ } \\
\text { Inne } \\
\text { oceny } \\
\text { ryzyka }\end{array}$ & $\chi^{2}$ \\
\hline \multirow{4}{*}{$\begin{array}{l}\text { Czech } \\
\text { Republic } \\
\text { Czechy }\end{array}$} & \multirow{2}{*}{$\begin{array}{l}\text { Drinkers } \\
\text { Pijący }\end{array}$} & 2911 & 15843 & \multirow{2}{*}{9.48} & 2163 & 12944 & \multirow{2}{*}{91.56} & 1246 & 8128 & \multirow{2}{*}{79.09} \\
\hline & & $16 \%$ & $85 \%$ & & $14 \%$ & $86 \%$ & & $13 \%$ & $87 \%$ & \\
\hline & \multirow{2}{*}{$\begin{array}{l}\text { Abstainers } \\
\text { Abstynenci }\end{array}$} & 267 & 1169 & \multirow{2}{*}{$p<0.01$} & 1015 & 4068 & \multirow{2}{*}{$p<0.001$} & 1932 & 8884 & \multirow{2}{*}{$p<0.001$} \\
\hline & & $19 \%$ & $81 \%$ & & $20 \%$ & $80 \%$ & & $18 \%$ & $82 \%$ & \\
\hline \multirow{4}{*}{$\begin{array}{l}\text { Denmark } \\
\text { Dania }\end{array}$} & \multirow{2}{*}{$\begin{array}{l}\text { Drinkers } \\
\text { Pijący }\end{array}$} & 1812 & 8485 & \multirow{2}{*}{14.84} & 1494 & 7232 & \multirow{2}{*}{20.4} & 1110 & 5425 & \multirow{2}{*}{10.47} \\
\hline & & $18 \%$ & $82 \%$ & & $17 \%$ & $83 \%$ & & $17 \%$ & $83 \%$ & \\
\hline & \multirow{2}{*}{$\begin{array}{l}\text { Abstainers } \\
\text { Abstynenci }\end{array}$} & 163 & 534 & \multirow{2}{*}{$p<0.001$} & 481 & 1787 & \multirow{2}{*}{$p<0.001$} & 865 & 3594 & \multirow{2}{*}{$p<0.01$} \\
\hline & & $23 \%$ & $77 \%$ & & $21 \%$ & $79 \%$ & & $19 \%$ & $81 \%$ & \\
\hline \multirow{4}{*}{$\begin{array}{l}\text { France } \\
\text { Francja }\end{array}$} & \multirow{2}{*}{$\begin{array}{l}\text { Drinkers } \\
\text { Pijący }\end{array}$} & 1704 & 8509 & \multirow{2}{*}{31.16} & 1224 & 6305 & \multirow{2}{*}{23.63} & 716 & 3976 & \multirow{2}{*}{28.55} \\
\hline & & $17 \%$ & $83 \%$ & & $16 \%$ & $84 \%$ & & $15 \%$ & $85 \%$ & \\
\hline & \multirow{2}{*}{$\begin{array}{l}\text { Abstainers } \\
\text { Abstynenci }\end{array}$} & 542 & 1990 & $n<0 \cap 01$ & 1022 & 4194 & & 1530 & 6523 & \\
\hline & & $21 \%$ & $79 \%$ & $p<0.001$ & $20 \%$ & $80 \%$ & 01 & $19 \%$ & $81 \%$ & 0.001 \\
\hline & Drinkers & 4962 & 18405 & & 3563 & 14509 & & 1915 & 8345 & \\
\hline Italy & Pijący & $21 \%$ & $79 \%$ & $1 / 5.56$ & $20 \%$ & $80 \%$ & 266.22 & $19 \%$ & $81 \%$ & 158.04 \\
\hline Włochy & Abstainers & 1715 & 4123 & & 3114 & 8019 & & 4762 & 14183 & \\
\hline & Abstynenci & $29 \%$ & $71 \%$ & $p$ & $28 \%$ & $72 \%$ & & $25 \%$ & $75 \%$ & 01 \\
\hline & Drinkers & 8426 & 20283 & 70 & 5555 & 14875 & & 3348 & 10446 & \\
\hline Poland & Pijący & $29 \%$ & $71 \%$ & 19 & $27 \%$ & $73 \%$ & 23 & $24 \%$ & $76 \%$ & 401.5 \\
\hline Polska & Abstainers & 2643 & 4992 & & 5514 & 10400 & & 7721 & 14829 & \\
\hline & Abstynenci & $35 \%$ & $65 \%$ & $p<0.001$ & $35 \%$ & $65 \%$ & $p<0.001$ & $34 \%$ & $66 \%$ & $p<0.001$ \\
\hline & Drinkers & 4630 & 8728 & 1168 & 2947 & 5568 & - & 2256 & 4361 & \\
\hline Sweden & Pijący & $35 \%$ & $65 \%$ & 11.68 & $35 \%$ & $65 \%$ & - & $34 \%$ & $66 \%$ & - \\
\hline Szwecja & Abstainers & 1563 & 3328 & & 3246 & 6488 & & 3937 & 7695 & \\
\hline & Abstynenci & $32 \%$ & $68 \%$ & & $33 \%$ & $67 \%$ & - & $34 \%$ & $66 \%$ & - \\
\hline & Drinkers & 5962 & 10823 & & 3834 & 7740 & & 2387 & 5421 & \\
\hline Ukraine & Pijący & $36 \%$ & $65 \%$ & 81.69 & $33 \%$ & $67 \%$ & $16 \% . / 2$ & $31 \%$ & $69 \%$ & 221.26 \\
\hline Ukraina & Abstainers & 1695 & 2223 & $n<0 \Omega 01$ & 3823 & 5306 & & 5270 & 7625 & \\
\hline & Abstynenci & $43 \%$ & $57 \%$ & $p<0.001$ & $42 \%$ & $58 \%$ & 1 & $41 \%$ & $59 \%$ & \\
\hline
\end{tabular}

this pattern of alcohol consumption as lowrisk or no-risk in Denmark, Italy and Ukraine $(p<0.001)$. In Denmark this trend was constant and almost linear: it led to an almost 3-fold decrease from $48 \%$ to $18 \%$. In other countries (e.g. in Poland) there were no statistically significant changes. However a downward trend was recorded in Poland and Denmark between 2011 and $2015(p<0.01)$, while an increase occurred only in Sweden $(p<0.01)$. oceniających ten wzór konsumpcji alkoholu jako mało ryzykowny bądź pozbawiony ryzyka $(p<0,001)$, przy czym w Danii trend ten miał stały, niemal liniowy charakter i doprowadził do blisko 3-krotnego spadku: z poziomu $48 \%$ do $18 \%$. $\mathrm{W}$ pozostałych krajach, m.in. w Polsce, nie odnotowano zmian istotnych statystycznie. Z kolei trend spadkowy w latach 2011-2015 odnotowano w Polsce i w Danii $(p<0,01)$, podczas gdy wzrost nastąpił jedynie w Szwecji $(p<0,01)$. 
Table IX. Low and high risk perception of binge drinking and abstinence in the previous 12 months, 30 days and binge drinking (all years) $\left(\chi^{2}\right)$

Tabela IX. Związek niskiej i wysokiej percepcji ryzyka upijania się i abstynencji w ciągu 12 miesięcy i 30 dni przed badaniem oraz upijania się (wszystkie lata) $\left(\chi^{2}\right)$

\begin{tabular}{|c|c|c|c|c|c|c|c|c|c|c|}
\hline & & \multicolumn{9}{|c|}{ Low risk/Niska ocena ryzyka } \\
\hline & & \multicolumn{3}{|c|}{12 months/miesięcy } & \multicolumn{3}{|c|}{30 days/dni } & \multicolumn{3}{|c|}{ Binge drinking/Upijanie się } \\
\hline & & $\begin{array}{l}\text { Low risk/ } \\
\text { Niskie } \\
\text { ryzyko }\end{array}$ & $\begin{array}{l}\text { Other } \\
\text { risks/ } \\
\text { Inne } \\
\text { oceny } \\
\text { ryzyka }\end{array}$ & $\chi^{2}$ & $\begin{array}{l}\text { Low risk/ } \\
\text { Niskie } \\
\text { ryzyko }\end{array}$ & $\begin{array}{l}\text { Other } \\
\text { risks/ } \\
\text { Inne } \\
\text { oceny } \\
\text { ryzyka }\end{array}$ & $\chi^{2}$ & $\begin{array}{l}\text { Low } \\
\text { risk/ } \\
\text { Niskie } \\
\text { ryzyko }\end{array}$ & $\begin{array}{l}\text { Other } \\
\text { risks/ } \\
\text { Inne } \\
\text { oceny } \\
\text { ryzyka }\end{array}$ & $\chi^{2}$ \\
\hline \multirow{4}{*}{$\begin{array}{l}\text { Czech } \\
\text { Republic } \\
\text { Czechy }\end{array}$} & \multirow{2}{*}{$\begin{array}{c}\text { Drinkers } \\
\text { Pijący }\end{array}$} & 4128 & 14626 & \multirow{2}{*}{52.66} & 3685 & 11422 & \multirow{2}{*}{312.5} & 2765 & 6609 & \multirow{2}{*}{675.95} \\
\hline & & $22 \%$ & $78 \%$ & & $24 \%$ & $76 \%$ & & $30 \%$ & $71 \%$ & \\
\hline & \multirow{2}{*}{$\begin{array}{l}\text { Abstainers } \\
\text { Abstynenci }\end{array}$} & 199 & 1237 & \multirow{2}{*}{$p<0.001$} & 642 & 4441 & \multirow{2}{*}{$p<0.001$} & 1562 & 9254 & \multirow{2}{*}{$p<0.001$} \\
\hline & & $14 \%$ & $86 \%$ & & $13 \%$ & $87 \%$ & & $14 \%$ & $86 \%$ & \\
\hline \multirow{4}{*}{$\begin{array}{l}\text { Denmark } \\
\text { Dania }\end{array}$} & \multirow{2}{*}{$\begin{array}{c}\text { Drinkers } \\
\text { Pijący }\end{array}$} & 3514 & 6783 & \multirow{2}{*}{115.74} & 3218 & 5508 & \multirow{2}{*}{307.59} & 2674 & 3861 & \multirow{2}{*}{472.66} \\
\hline & & $34 \%$ & $66 \%$ & & $37 \%$ & $63 \%$ & & $41 \%$ & $59 \%$ & \\
\hline & \multirow{2}{*}{$\begin{array}{l}\text { Abstainers } \\
\text { Abstynenci }\end{array}$} & 100 & 597 & \multirow{2}{*}{$p<0.001$} & 396 & 1872 & \multirow{2}{*}{$p<0.001$} & 940 & 3519 & \multirow{2}{*}{$p<0.001$} \\
\hline & & $14 \%$ & $86 \%$ & & $18 \%$ & $83 \%$ & & $21 \%$ & $79 \%$ & \\
\hline \multirow{4}{*}{$\begin{array}{l}\text { France } \\
\text { Francja }\end{array}$} & \multirow{2}{*}{$\begin{array}{c}\text { Drinkers } \\
\text { Pijący }\end{array}$} & 1484 & 8729 & \multirow{2}{*}{108.6} & 1303 & 6226 & \multirow{2}{*}{303.98} & 1023 & 3669 & \multirow{2}{*}{510.96} \\
\hline & & $15 \%$ & $86 \%$ & & $17 \%$ & $83 \%$ & & $22 \%$ & $78 \%$ & \\
\hline & \multirow{2}{*}{$\begin{array}{l}\text { Abstainers } \\
\text { Abstynenci }\end{array}$} & 171 & 2361 & $n \in 0001$ & 352 & 4864 & & 632 & 7421 & 001 \\
\hline & & $7 \%$ & $93 \%$ & $p<0.001$ & $7 \%$ & $93 \%$ & .001 & $8 \%$ & $92 \%$ & $p<0.001$ \\
\hline & Drinkers & 3973 & 19394 & 203 & 3436 & 14636 & & 2487 & 7773 & 02398 \\
\hline Italy & Pijący & $17 \%$ & $83 \%$ & 203.21 & $19 \%$ & $81 \%$ & כנד & $24 \%$ & $76 \%$ & 923.90 \\
\hline Włochy & Abstainers & 552 & 5286 & & 1089 & 10044 & & 2038 & 16907 & \\
\hline & Abstynenci & $10 \%$ & $91 \%$ & 0.001 & $10 \%$ & $90 \%$ & .001 & $11 \%$ & $89 \%$ & $p<0.001$ \\
\hline & Drinkers & 5089 & 23620 & 37582 & 4137 & 16293 & 68995 & 3248 & 10546 & 09884 \\
\hline Poland & Pijący & $18 \%$ & $82 \%$ & (3/5.02 & $20 \%$ & $80 \%$ & בעב 009. & $24 \%$ & $77 \%$ & 990.04 \\
\hline Polska & Abstainers & 658 & 6977 & & 1610 & 14304 & & 2499 & 20051 & 1 \\
\hline & Abstynenci & $9 \%$ & $91 \%$ & 0.001 & $10 \%$ & $90 \%$ & .001 & $11 \%$ & $89 \%$ & 0.001 \\
\hline & Drinkers & 2313 & 11045 & & 1750 & 6765 & & 1479 & 5138 & \\
\hline Sweden & Pijący & $17 \%$ & $83 \%$ & 244.14 & $21 \%$ & $79 \%$ & 414.1 & $22 \%$ & $78 \%$ & 465.24 \\
\hline Szwecja & Abstainers & 393 & 4498 & $n<0 \Omega 01$ & 956 & 8778 & $n<0 \cap 01$ & 1227 & 10405 & (2001 \\
\hline & Abstyn & $8 \%$ & $92 \%$ & 0.001 & $10 \%$ & $90 \%$ & $p<0.001$ & $11 \%$ & $90 \%$ & .001 \\
\hline & Drinkers & 1991 & 14794 & 3717 & 1536 & 10038 & & 1241 & 6567 & 51 \\
\hline Ukraine & Pijący & $12 \%$ & $88 \%$ & 37.17 & $13 \%$ & $87 \%$ & 111.35 & $16 \%$ & $84 \%$ & 273.51 \\
\hline Ukraina & Abstainers & 331 & 3587 & & 786 & 8343 & 0.001 & 1081 & 11814 & \\
\hline & Abstynenci & $8 \%$ & $92 \%$ & $\rho<0.001$ & $9 \%$ & $91 \%$ & $\rho<0.001$ & $8 \%$ & $92 \%$ & . \\
\hline
\end{tabular}

Between 1995 and 2015, there was an increase in the percentage of students who assessed binge drinking as a highly risky behaviour in all of the analysed countries (with the exception of the Czech Republic) (Table VII). These changes were statistically significant in most countries $(p<0.001-p<0.05)$, with the exception of Sweden, where only a slight increase was recorded. The largest and consistent increase took place
W latach 1995-2015 we wszystkich analizowanych krajach, z wyjątkiem Czech, nastąpił wzrost odsetka uczniów, którzy oceniali upijanie się jako zachowanie wysoce ryzykowne (tab. VII). Zmiany te były istotne statystycznie w większości krajów $(p<0,001-p<0,05)$, z wyjątkiem Szwecji, gdzie odnotowano jedynie nieznaczny wzrost. Największy i jednocześnie konsekwentny wzrost miał miejsce w Danii, 
Table IX. Continued

Tabela IX. Ciąg dalszy

\begin{tabular}{|c|c|c|c|c|c|c|c|c|c|c|}
\hline & & \multicolumn{9}{|c|}{ High risk/Wysoka ocena ryzyka } \\
\hline & & \multicolumn{3}{|c|}{12 months/miesięcy } & \multicolumn{3}{|c|}{30 days/dni } & \multicolumn{3}{|c|}{ Binge drinking/Upijanie się } \\
\hline & & $\begin{array}{l}\text { High risk/ } \\
\text { Wysokie } \\
\text { ryzyko }\end{array}$ & $\begin{array}{l}\text { Other } \\
\text { risks/ } \\
\text { Inne } \\
\text { oceny } \\
\text { ryzyka }\end{array}$ & $\chi^{2}$ & $\begin{array}{c}\text { High risk/ } \\
\text { Wysokie } \\
\text { ryzyko }\end{array}$ & $\begin{array}{l}\text { Other } \\
\text { risks/ } \\
\text { Inne } \\
\text { oceny } \\
\text { ryzyka }\end{array}$ & $\chi^{2}$ & $\begin{array}{c}\text { High } \\
\text { risk/ } \\
\text { Wysokie } \\
\text { ryzyko }\end{array}$ & $\begin{array}{l}\text { Other } \\
\text { risks/ } \\
\text { Inne } \\
\text { oceny } \\
\text { ryzyka }\end{array}$ & $\chi^{2}$ \\
\hline \multirow{4}{*}{$\begin{array}{l}\text { Czech } \\
\text { Republic } \\
\text { Czechy }\end{array}$} & \multirow{2}{*}{$\begin{array}{l}\text { Drinkers } \\
\text { Pijący }\end{array}$} & 6128 & 12626 & \multirow{2}{*}{79.8} & 4586 & 10521 & \multirow{2}{*}{265.59} & 2504 & 6870 & \multirow{2}{*}{361.57} \\
\hline & & $33 \%$ & $67 \%$ & & $30 \%$ & $70 \%$ & & $27 \%$ & $73 \%$ & \\
\hline & \multirow{2}{*}{$\begin{array}{l}\text { Abstainers } \\
\text { Abstynenci }\end{array}$} & 635 & 801 & \multirow{2}{*}{$p<0.001$} & 2177 & 2906 & \multirow{2}{*}{$p<0.001$} & 4259 & 6557 & \multirow{2}{*}{$p<0.001$} \\
\hline & & $44 \%$ & $56 \%$ & & $43 \%$ & $57 \%$ & & $39 \%$ & $61 \%$ & \\
\hline \multirow{4}{*}{$\begin{array}{l}\text { Denmark } \\
\text { Dania }\end{array}$} & \multirow{2}{*}{$\begin{array}{l}\text { Drinkers } \\
\text { Pijący }\end{array}$} & 2458 & 7839 & \multirow{2}{*}{145.12} & 1886 & 6840 & \multirow{2}{*}{283.79} & 1251 & 5284 & \multirow{2}{*}{310.58} \\
\hline & & $24 \%$ & $76 \%$ & & $22 \%$ & $78 \%$ & & $19 \%$ & $81 \%$ & \\
\hline & \multirow{2}{*}{$\begin{array}{l}\text { Abstainers } \\
\text { Abstynenci }\end{array}$} & 309 & 388 & \multirow{2}{*}{$p<0.001$} & 881 & 1387 & \multirow{2}{*}{$p<0.001$} & 1516 & 2943 & \multirow{2}{*}{$p<0.001$} \\
\hline & & $44 \%$ & $56 \%$ & & $39 \%$ & $61 \%$ & & $34 \%$ & $66 \%$ & \\
\hline \multirow{4}{*}{$\begin{array}{l}\text { France } \\
\text { Francja }\end{array}$} & \multirow{2}{*}{$\begin{array}{l}\text { Drinkers } \\
\text { Pijący }\end{array}$} & 3485 & 6728 & \multirow{2}{*}{126.18} & 2415 & 5114 & \multirow{2}{*}{625.87} & 1214 & 3478 & \multirow{2}{*}{362.3} \\
\hline & & $34 \%$ & $66 \%$ & & $32 \%$ & $68 \%$ & & $26 \%$ & $74 \%$ & \\
\hline & \multirow{2}{*}{$\begin{array}{l}\text { Abstainers } \\
\text { Abstynenci }\end{array}$} & 1168 & 1364 & $n, \cap \cap 01$ & 2238 & 2978 & & 3439 & 4614 & \\
\hline & & $46 \%$ & $54 \%$ & $p<0.001$ & $43 \%$ & $57 \%$ & 001 & $43 \%$ & $57 \%$ & .001 \\
\hline & Drinkers & 9380 & 13987 & 211 & 6710 & 11362 & & 3210 & 7050 & \\
\hline Italy & Pijący & $40 \%$ & $60 \%$ & 341 & $37 \%$ & $63 \%$ & 625.81 & $31 \%$ & $69 \%$ & 858.51 \\
\hline Włochy & Abstainers & 3124 & 2714 & & 5794 & 5339 & & 9294 & 9651 & \\
\hline & Abstynenci & $54 \%$ & $47 \%$ & $p$ & $52 \%$ & $48 \%$ & & $49 \%$ & $51 \%$ & 01 \\
\hline & Drinkers & 11840 & 16869 & & 7760 & 12670 & & 4755 & 9039 & \\
\hline Poland & Pijący & $41 \%$ & $59 \%$ & 463.1 & $38 \%$ & $62 \%$ & 115.84 & $35 \%$ & $66 \%$ & 841.82 \\
\hline Polska & Abstainers & 4200 & 3435 & & 8280 & 7634 & $n<\cap \cap 01$ & 11285 & 11265 & $n$ \\
\hline & Abstynenci & $55 \%$ & $45 \%$ & 0.001 & $52 \%$ & $48 \%$ & $p<0.001$ & $50 \%$ & $50 \%$ & $p<0.001$ \\
\hline & Drinkers & 5523 & 7835 & 25617 & 3222 & 5293 & 32778 & 2413 & 4204 & \\
\hline Sweden & Pijący & $41 \%$ & $59 \%$ & & $38 \%$ & $62 \%$ & 322.18 & $37 \%$ & $64 \%$ & \\
\hline Szwecja & Abstainers & 2673 & 2218 & & 4974 & 4760 & & 5783 & 5849 & \\
\hline & Abstynenci & $55 \%$ & $45 \%$ & & $51 \%$ & $49 \%$ & & $50 \%$ & $50 \%$ & 01 \\
\hline & Drinkers & 8223 & 8562 & & 5369 & 6205 & & 3330 & 4478 & \\
\hline Ukraine & Pijący & $49 \%$ & $51 \%$ & 18.31 & $46 \%$ & $54 \%$ & $1 / 5$ & $43 \%$ & $57 \%$ & $30 \% .23$ \\
\hline Ukraina & Abstainers & 2227 & 1691 & $n<0 \quad \rightarrow \quad \rightarrow$ & 5081 & 4048 & & 7120 & 5775 & \\
\hline & Abstynenci & $57 \%$ & $43 \%$ & $p<0.001$ & $56 \%$ & $44 \%$ & & $55 \%$ & $45 \%$ & 0.001 \\
\hline
\end{tabular}

in Denmark, where the number of students assessing binge drinking as a high-risk behaviour increased 3-fold and in Italy, where it increased by $2 / 3$. Between 2011 and 2015, the percentage of students assessing binge drinking as a highrisk behaviour increased in Poland as well as in Denmark, France and Italy. These changes were statistically significant $(p<0.01-p<0.001)$. The only statistically significant decrease in this gdzie liczba uczniów oceniających upijanie się jako zachowanie wysoce ryzykowne wzrosła 3-krotnie oraz we Włoszech, gdzie nastąpił wzrost o 2/3. Z kolei między rokiem 2011 a 2015 odsetek uczniów oceniających upijanie się jako zachowanie wysoce ryzykowne wzrósł w Polsce oraz w Danii, Francji i we Włoszech. Zmiany te były istotne statystycznie $(p<0,01-p<0,001)$. Jedyny, istotny statystycznie spadek w tym okresie 
Table X. Low and high risk perception of frequently drinking small amounts of alcohol and abstinence in the previous 12 months, 30 days and binge drinking (1995) $\left(\chi^{2}\right)$

Tabela X. Związek niskiej i wysokiej percepcji ryzyka częstego spożywania niewielkich ilości alkoholu i abstynencji w ciągu 12 miesięcy i 30 dni przed badaniem oraz upijania się (1995) $\left(\chi^{2}\right)$

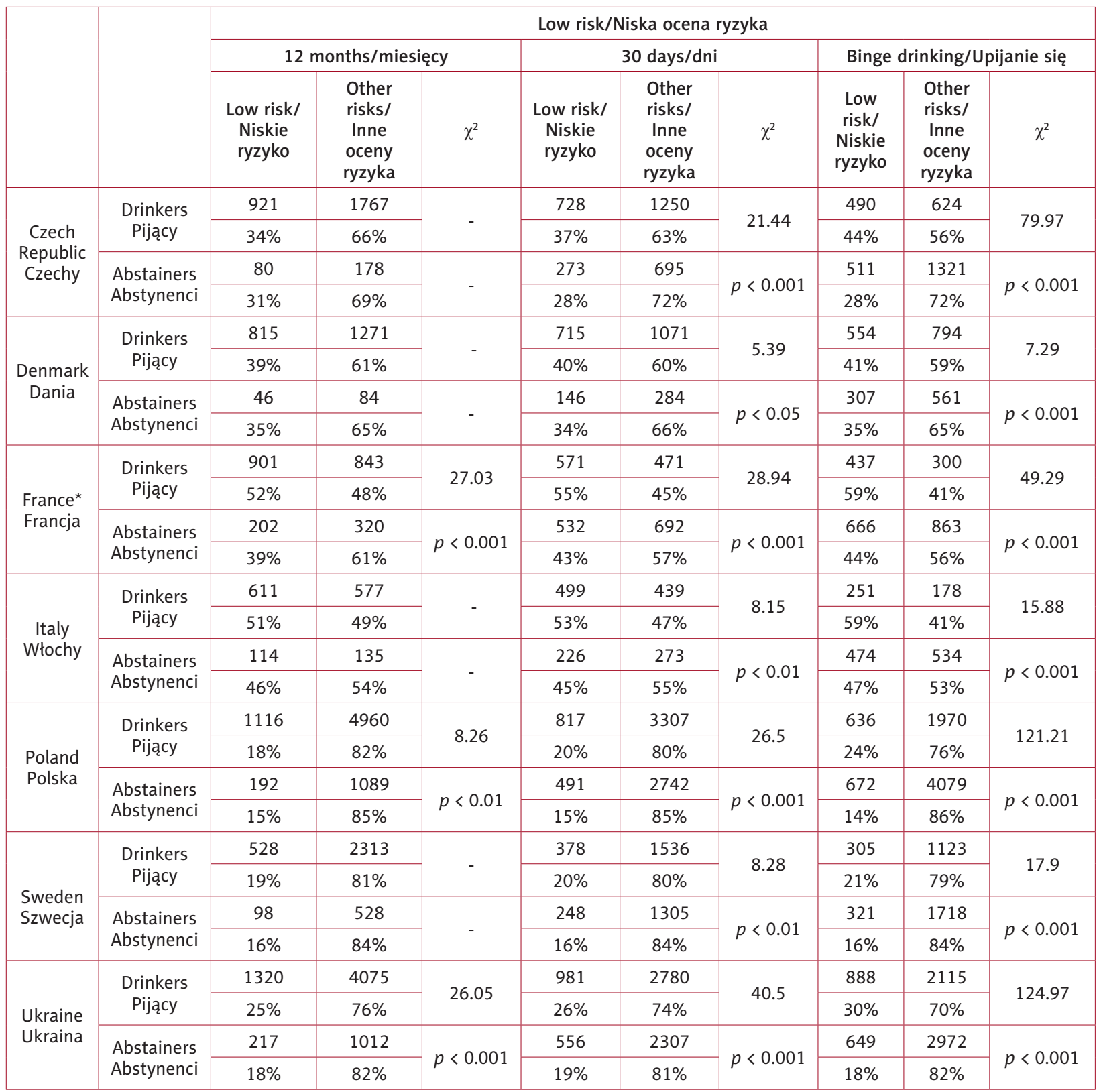

period was recorded in Sweden $(p<0.05)$, while no changes were noted in the Czech Republic and Ukraine.

Risk perception and alcohol consumption and binge drinking

Based on the analysis of aggregated data from all ESPAD survey measurements, it can be con- odnotowano w Szwecji ( $p<0,05)$, podczas gdy w Czechach i na Ukrainie nie odnotowano żadnych zmian.

Percepcja ryzyka a konsumpcja alkoholu i upijanie się

Na podstawie analizy zagregowanych danych ze wszystkich pomiarów badań ESPAD można stwier- 
Table X. Continued

Tabela X. Ciąg dalszy

\begin{tabular}{|c|c|c|c|c|c|c|c|c|c|c|}
\hline & & \multicolumn{9}{|c|}{ High risk/Wysoka ocena ryzyka } \\
\hline & & \multicolumn{3}{|c|}{12 months/miesięcy } & \multicolumn{3}{|c|}{30 days/dni } & \multicolumn{3}{|c|}{ Binge drinking/Upijanie się } \\
\hline & & $\begin{array}{l}\text { High risk/ } \\
\text { Wysokie } \\
\text { ryzyko }\end{array}$ & $\begin{array}{l}\text { Other } \\
\text { risks/ } \\
\text { Inne } \\
\text { oceny } \\
\text { ryzyka }\end{array}$ & $\chi^{2}$ & $\begin{array}{c}\text { High } \\
\text { risk/ } \\
\text { Wysokie } \\
\text { ryzyko }\end{array}$ & $\begin{array}{c}\text { Other } \\
\text { risks/ } \\
\text { Inne } \\
\text { oceny } \\
\text { ryzyka }\end{array}$ & $\chi^{2}$ & $\begin{array}{l}\text { High risk/ } \\
\text { Wysokie } \\
\text { ryzyko }\end{array}$ & $\begin{array}{l}\text { Other } \\
\text { risks/ } \\
\text { Inne } \\
\text { oceny } \\
\text { ryzyka }\end{array}$ & $\chi^{2}$ \\
\hline \multirow{4}{*}{$\begin{array}{l}\text { Czech } \\
\text { Republic } \\
\text { Czechy }\end{array}$} & \multirow{2}{*}{$\begin{array}{l}\text { Drinkers } \\
\text { Pijący }\end{array}$} & 680 & 2008 & \multirow{2}{*}{ - } & 487 & 1491 & \multirow{2}{*}{ - } & 230 & 884 & \multirow{2}{*}{22.15} \\
\hline & & $25 \%$ & $75 \%$ & & $25 \%$ & $75 \%$ & & $21 \%$ & $79 \%$ & \\
\hline & \multirow{2}{*}{$\begin{array}{l}\text { Abstainers } \\
\text { Abstynenci }\end{array}$} & 71 & 187 & \multirow{2}{*}{-} & 264 & 704 & \multirow{2}{*}{-} & 521 & 1311 & \multirow{2}{*}{$p<0.001$} \\
\hline & & $28 \%$ & $73 \%$ & & $27 \%$ & $73 \%$ & & $28 \%$ & $72 \%$ & \\
\hline \multirow{4}{*}{$\begin{array}{l}\text { Denmark } \\
\text { Dania }\end{array}$} & \multirow{2}{*}{$\begin{array}{c}\text { Drinkers } \\
\text { Pijący }\end{array}$} & 321 & 1765 & \multirow{2}{*}{-} & 271 & 1515 & \multirow{2}{*}{-} & 199 & 1149 & \multirow{2}{*}{ 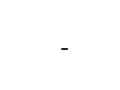 } \\
\hline & & $15 \%$ & $85 \%$ & & $15 \%$ & $85 \%$ & & $15 \%$ & $85 \%$ & \\
\hline & \multirow{2}{*}{$\begin{array}{l}\text { Abstainers } \\
\text { Abstynenci }\end{array}$} & 22 & 108 & \multirow{2}{*}{ - } & 72 & 358 & \multirow{2}{*}{ - } & 144 & 724 & \multirow{2}{*}{ - } \\
\hline & & $17 \%$ & $83 \%$ & & $17 \%$ & $83 \%$ & & $17 \%$ & $83 \%$ & \\
\hline \multirow{4}{*}{$\begin{array}{l}\text { France* }^{*} \\
\text { Francja }\end{array}$} & \multirow{2}{*}{$\begin{array}{c}\text { Drinkers } \\
\text { Pijący }\end{array}$} & 220 & 1524 & \multirow{2}{*}{18.4} & 126 & 916 & \multirow{2}{*}{7.95} & 242 & 1287 & \multirow{2}{*}{8.48} \\
\hline & & $13 \%$ & $87 \%$ & & $12 \%$ & $88 \%$ & & $16 \%$ & $84 \%$ & \\
\hline & \multirow{2}{*}{$\begin{array}{l}\text { Abstainers } \\
\text { Abstynenci }\end{array}$} & 105 & 417 & & 199 & 1025 & & 83 & 654 & \\
\hline & & $20 \%$ & $80 \%$ & 0.001 & $16 \%$ & $84 \%$ & 0.01 & $11 \%$ & $89 \%$ & $p<0.01$ \\
\hline & Drinkers & 145 & 1043 & 11 & 107 & 831 & 667 & 39 & 390 & 057 \\
\hline Italy & Pijący & $12 \%$ & $88 \%$ & 4.04 & $11 \%$ & $89 \%$ & 0.01 & $9 \%$ & $91 \%$ & ד \\
\hline Włochy & Abstainers & 43 & 206 & & 81 & 418 & & 149 & 859 & 01 \\
\hline & Abstynenci & $17 \%$ & $83 \%$ & $p<0.05$ & $16 \%$ & $84 \%$ & .05 & $15 \%$ & $85 \%$ & $p<0.01$ \\
\hline & Drinkers & 2243 & 3833 & & 1457 & 2667 & 000 & 803 & 1803 & 62 \\
\hline Poland & Pijący & $37 \%$ & $63 \%$ & & $35 \%$ & $65 \%$ & 8.98 & $31 \%$ & $69 \%$ & 02.03 \\
\hline Polska & Abstainers & 466 & 815 & & 1252 & 1981 & ( $\cap \cap 1$ & 1906 & 2845 & (2001 \\
\hline & Abstynenci & $36 \%$ & $64 \%$ & - & $39 \%$ & $61 \%$ & $p<0.01$ & $40 \%$ & $60 \%$ & $p<0.001$ \\
\hline & Drinkers & 1171 & 1670 & & 792 & 1122 & & 574 & 854 & \\
\hline & Pijący & $41 \%$ & $59 \%$ & - & $41 \%$ & $59 \%$ & - & $40 \%$ & $60 \%$ & - \\
\hline Szwecja & Abstainers & 258 & 368 & & 637 & 916 & & 855 & 1184 & \\
\hline & Abstynenci & $41 \%$ & $59 \%$ & & $41 \%$ & $59 \%$ & & $42 \%$ & $58 \%$ & \\
\hline & Drinkers & 1850 & 3545 & 2625 & 1198 & 2563 & 5706 & 868 & 2135 & 11157 \\
\hline Ukraine & Pijący & $34 \%$ & $66 \%$ & 20.35 & $32 \%$ & $68 \%$ & 31.00 & $29 \%$ & $71 \%$ & $111.3 /$ \\
\hline Ukraina & Abstainers & 517 & 712 & PO1 & 1169 & 1694 & & 1499 & 2122 & 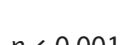 \\
\hline & Abstynenci & $42 \%$ & $58 \%$ & 0.001 & $41 \%$ & $59 \%$ & 0.001 & $41 \%$ & $59 \%$ & 0.001 \\
\hline
\end{tabular}

*1999

cluded that in each of the analysed countries (except Sweden) both low and high risk assessment of frequent consumption of small amounts of alcohol was related to having consumed alcohol within the previous 12 months $(p<0.001)$ and 30 days before the survey $(p<0.001)$ as well as engaging in binge drinking $(p<0.001)$ (Table VIII). Abstainers more often rated the risk of binge drinking as high, while drinkers more often rated it as low. Similar- dzić, że w każdym $\mathrm{z}$ analizowanych krajów (z wyjątkiem Szwecji) zarówno niska, jak i wysoka ocena ryzyka częstego spożywania niewielkich ilości alkoholu miała związek $\mathrm{z}$ faktem sięgania po alkohol w ciągu 12 miesięcy $(p<0,001)$ i 30 dni przed badaniem $(p<0,001)$ oraz z upijaniem się $(p<0,001)$ (tab. VIII). Abstynenci częściej oceniali ryzyko upijania się jako wysokie, podczas gdy pijący częściej oceniali je jako niskie. Podobnie, we wszystkich 
Table XI. Low and high risk perception of binge drinking and abstinence in the previous 12 months, 30 days and binge drinking (1995) $\left(\chi^{2}\right)$

Tabela XI. Związek niskiej i wysokiej percepcji ryzyka upijania się i abstynencji w ciągu 12 miesięcy i 30 dni przed badaniem oraz upijania się (1995) $\left(\chi^{2}\right)$

\begin{tabular}{|c|c|c|c|c|c|c|c|c|c|c|}
\hline & & \multicolumn{9}{|c|}{ Low risk/Niska ocena ryzyka } \\
\hline & & \multicolumn{3}{|c|}{12 months/miesięcy } & \multicolumn{3}{|c|}{30 days/dni } & \multicolumn{3}{|c|}{ Binge drinking/Upijanie się } \\
\hline & & $\begin{array}{l}\text { Low risk/ } \\
\text { Niskie } \\
\text { ryzyko }\end{array}$ & $\begin{array}{l}\text { Other } \\
\text { risks/ } \\
\text { Inne } \\
\text { oceny } \\
\text { ryzyka }\end{array}$ & $\chi^{2}$ & $\begin{array}{l}\text { Low risk/ } \\
\text { Niskie } \\
\text { ryzyko }\end{array}$ & $\begin{array}{l}\text { Other } \\
\text { risks/ } \\
\text { Inne } \\
\text { oceny } \\
\text { ryzyka }\end{array}$ & $\chi^{2}$ & $\begin{array}{c}\text { Low } \\
\text { risk/ } \\
\text { Niskie } \\
\text { ryzyko }\end{array}$ & $\begin{array}{l}\text { Other } \\
\text { risks/ } \\
\text { Inne } \\
\text { oceny } \\
\text { ryzyka }\end{array}$ & $\chi^{2}$ \\
\hline \multirow{4}{*}{$\begin{array}{l}\text { Czech } \\
\text { Republic } \\
\text { Czechy }\end{array}$} & \multirow{2}{*}{$\begin{array}{c}\text { Drinkers } \\
\text { Pijący }\end{array}$} & 501 & 2187 & \multirow{2}{*}{5.42} & 428 & 1550 & \multirow{2}{*}{50.02} & 317 & 797 & \multirow{2}{*}{128.8} \\
\hline & & $19 \%$ & $81 \%$ & & $22 \%$ & $78 \%$ & & $29 \%$ & $72 \%$ & \\
\hline & \multirow{2}{*}{$\begin{array}{l}\text { Abstainers } \\
\text { Abstynenci }\end{array}$} & 33 & 225 & \multirow{2}{*}{$p<0.05$} & 106 & 862 & \multirow{2}{*}{$p<0.001$} & 217 & 1615 & \multirow{2}{*}{$p<0.001$} \\
\hline & & $13 \%$ & $87 \%$ & & $11 \%$ & $89 \%$ & & $12 \%$ & $88 \%$ & \\
\hline \multirow{4}{*}{$\begin{array}{l}\text { Denmark } \\
\text { Dania }\end{array}$} & \multirow{2}{*}{$\begin{array}{c}\text { Drinkers } \\
\text { Pijący }\end{array}$} & 1020 & 1066 & \multirow{2}{*}{27.13} & 922 & 864 & \multirow{2}{*}{62.21} & 751 & 597 & \multirow{2}{*}{92.66} \\
\hline & & $49 \%$ & $51 \%$ & & $52 \%$ & $48 \%$ & & $56 \%$ & $44 \%$ & \\
\hline & \multirow{2}{*}{$\begin{array}{l}\text { Abstainers } \\
\text { Abstynenci }\end{array}$} & 33 & 97 & \multirow{2}{*}{$p<0.001$} & 131 & 299 & \multirow{2}{*}{$p<0.001$} & 302 & 566 & \multirow{2}{*}{$p<0.001$} \\
\hline & & $25 \%$ & $75 \%$ & & $31 \%$ & $70 \%$ & & $35 \%$ & $65 \%$ & \\
\hline \multirow{4}{*}{$\begin{array}{l}\text { France* } \\
\text { Francja }\end{array}$} & \multirow{2}{*}{$\begin{array}{l}\text { Drinkers } \\
\text { Pijący }\end{array}$} & 273 & 1546 & \multirow{2}{*}{21.47} & 230 & 1063 & \multirow{2}{*}{50.92} & 172 & 476 & \multirow{2}{*}{136.26} \\
\hline & & $15 \%$ & $85 \%$ & & $18 \%$ & $82 \%$ & & $26 \%$ & $74 \%$ & \\
\hline & \multirow{2}{*}{$\begin{array}{l}\text { Abstainers } \\
\text { Abstynenci }\end{array}$} & 31 & 427 & $n<\cap 001$ & 74 & 910 & 01 & 132 & 1497 & لح \\
\hline & & $7 \%$ & $93 \%$ & $p<0.001$ & $7 \%$ & $93 \%$ & 1 & $8 \%$ & $92 \%$ & $p<0.001$ \\
\hline & Drinkers & 288 & 900 & 062 & 248 & 690 & 2085 & 149 & 280 & 409 \\
\hline Italy & Pijący & $24 \%$ & $76 \%$ & 0.02 & $26 \%$ & $74 \%$ & 20.03 & $35 \%$ & $65 \%$ & 49.9 \\
\hline Włochy & Abstainers & 39 & 210 & & 79 & 420 & & 178 & 830 & 001 \\
\hline & Abstynenci & $16 \%$ & $84 \%$ & $p<0.01$ & $16 \%$ & $84 \%$ & $p<0.001$ & $18 \%$ & $82 \%$ & $p<0.001$ \\
\hline & Drinkers & 995 & 5081 & 1875 & 744 & 3380 & 6 & 574 & 2032 & 52 \\
\hline Poland & Pijacy & $16 \%$ & $84 \%$ & 10.15 & $18 \%$ & $82 \%$ & 47.00 & $22 \%$ & $78 \%$ & 129.02 \\
\hline Polska & Abstainers & 148 & 1133 & & 399 & 2834 & & 569 & 4182 & 1 \\
\hline & Abstynenci & $12 \%$ & $88 \%$ & 0.001 & $12 \%$ & $88 \%$ & 0.001 & $12 \%$ & $88 \%$ & $p>0.001$ \\
\hline & Drinkers & 498 & 2343 & 5206 & 404 & 1510 & 1055 & 345 & 1083 & 14175 \\
\hline Sweden & Pijący & $18 \%$ & $83 \%$ & 33.00 & $21 \%$ & $79 \%$ & 103.3 & $24 \%$ & $76 \%$ & 141.72 \\
\hline Szwecja & Abstainers & 37 & 589 & & 131 & 1422 & & 190 & 1849 & > \\
\hline & Abstynenci & $6 \%$ & $94 \%$ & 0.001 & $8 \%$ & $92 \%$ & 001 & $9 \%$ & $91 \%$ & 0.001 \\
\hline & Drinkers & 607 & 4788 & 012 & 486 & 3275 & 1101 & 450 & 2553 & 105,26 \\
\hline Ukraine & Pijący & $11 \%$ & $89 \%$ & 3.12 & $13 \%$ & $87 \%$ & 44.01 & $15 \%$ & $85 \%$ & 10.50 \\
\hline Ukraina & Abstainers & 102 & 1127 & $n<001$ & 223 & 2640 & 1 & 259 & 3362 & 01 \\
\hline & Abstynenci & $8 \%$ & $92 \%$ & $p<0.01$ & $8 \%$ & $92 \%$ & $p<0.001$ & $7 \%$ & $93 \%$ & $p<0.001$ \\
\hline
\end{tabular}

ly, in all countries, a low vs. high risk assessment of binge drinking was related to abstaining from alcohol for all three indicators (Table IX). This seemingly easy-to-predict picture of distribution of risk assessments has changed over the years.

In 1995, the relationship between low-risk assessments of consumption of small amounts of alcohol and drinking in the previous 12 months was recorded only in Poland and Ukraine $(p<0.001-$ krajach niska, a także wysoka ocena ryzyka upijania się pozostawała $\mathrm{w}$ związku z postawami abstynencji od alkoholu we wszystkich trzech wskaźnikach (tab. IX). Ten pozornie łatwy do przewidzenia obraz dystrybucji ocen ryzyka ulegał zmianom na przestrzeni lat.

W 1995 roku związek ocen niskiego ryzyka spożywania niewielkich ilości alkoholu i sięgania po alkohol w ciągu ostatnich 12 miesięcy został odnotowany jedynie w Polsce i na Ukrainie 
Table XI. Continued

Tabela XI. Ciąg dalszy

\begin{tabular}{|c|c|c|c|c|c|c|c|c|c|c|}
\hline & & \multicolumn{9}{|c|}{ High risk/Wysoka ocena ryzyka } \\
\hline & & \multicolumn{3}{|c|}{12 months/miesięcy } & \multicolumn{3}{|c|}{30 days/dni } & \multicolumn{3}{|c|}{ Binge drinking/Upijanie się } \\
\hline & & $\begin{array}{l}\text { High risk/ } \\
\text { Wysokie } \\
\text { ryzyko }\end{array}$ & $\begin{array}{c}\text { Other } \\
\text { risks/ } \\
\text { Inne } \\
\text { oceny } \\
\text { ryzyka }\end{array}$ & $\chi^{2}$ & $\begin{array}{c}\text { High } \\
\text { risk/ } \\
\text { Wysokie } \\
\text { ryzyko }\end{array}$ & $\begin{array}{l}\text { Other } \\
\text { risks/ } \\
\text { Inne } \\
\text { oceny } \\
\text { ryzyka }\end{array}$ & $\chi^{2}$ & $\begin{array}{c}\text { High risk/ } \\
\text { Wysokie } \\
\text { ryzyko }\end{array}$ & $\begin{array}{l}\text { Other } \\
\text { risks/ } \\
\text { Inne } \\
\text { oceny } \\
\text { ryzyka }\end{array}$ & $\chi^{2}$ \\
\hline \multirow{4}{*}{$\begin{array}{l}\text { Czech } \\
\text { Republic } \\
\text { Czechy }\end{array}$} & \multirow{2}{*}{$\begin{array}{l}\text { Drinkers } \\
\text { Pijący }\end{array}$} & 1019 & 1669 & \multirow{2}{*}{9.46} & 678 & 1300 & \multirow{2}{*}{51.06} & 320 & 794 & \multirow{2}{*}{76.06} \\
\hline & & $38 \%$ & $62 \%$ & & $34 \%$ & $66 \%$ & & $29 \%$ & $71 \%$ & \\
\hline & \multirow{2}{*}{$\begin{array}{l}\text { Abstainers } \\
\text { Abstynenci }\end{array}$} & 123 & 135 & \multirow{2}{*}{$p<0.01$} & 464 & 504 & \multirow{2}{*}{$p<0.001$} & 822 & 1010 & \multirow{2}{*}{$p<0.001$} \\
\hline & & $48 \%$ & $52 \%$ & & $48 \%$ & $52 \%$ & & $45 \%$ & $55 \%$ & \\
\hline \multirow{4}{*}{$\begin{array}{l}\text { Denmark } \\
\text { Dania }\end{array}$} & \multirow{2}{*}{$\begin{array}{c}\text { Drinkers } \\
\text { Pijący }\end{array}$} & 249 & 1837 & \multirow{2}{*}{10.31} & 186 & 1600 & \multirow{2}{*}{36.6} & 125 & 1223 & \multirow{2}{*}{32.77} \\
\hline & & $12 \%$ & $88 \%$ & & $10 \%$ & $90 \%$ & & $9 \%$ & $91 \%$ & \\
\hline & \multirow{2}{*}{$\begin{array}{l}\text { Abstainers } \\
\text { Abstynenci }\end{array}$} & 28 & 102 & \multirow{2}{*}{$p<0.01$} & 91 & 339 & \multirow{2}{*}{$p<0.001$} & 152 & 716 & \multirow{2}{*}{$p<0.001$} \\
\hline & & $22 \%$ & $79 \%$ & & $21 \%$ & $79 \%$ & & $18 \%$ & $83 \%$ & \\
\hline \multirow{4}{*}{$\begin{array}{l}\text { France* } \\
\text { Francja }\end{array}$} & \multirow{2}{*}{$\begin{array}{l}\text { Drinkers } \\
\text { Pijący }\end{array}$} & 850 & 969 & \multirow{2}{*}{50.39} & 558 & 735 & \multirow{2}{*}{63.88} & 207 & 441 & \multirow{2}{*}{124.23} \\
\hline & & $47 \%$ & $53 \%$ & & $43 \%$ & $57 \%$ & & $32 \%$ & $68 \%$ & \\
\hline & \multirow{2}{*}{$\begin{array}{l}\text { Abstainers } \\
\text { Abstynenci }\end{array}$} & 299 & 159 & & 591 & 393 & & 942 & 687 & \\
\hline & & $65 \%$ & $35 \%$ & $p<0.001$ & $60 \%$ & $40 \%$ & $p<0.001$ & $58 \%$ & $42 \%$ & $p<0.001$ \\
\hline & Drinkers & 339 & 849 & & 255 & 683 & & 92 & 337 & \\
\hline Italy & Pijący & $29 \%$ & $72 \%$ & 24.63 & $27 \%$ & $73 \%$ & 21.42 & $21 \%$ & $79 \%$ & 27.7 \\
\hline Włochy & Abstainers & 111 & 138 & & 195 & 304 & & 358 & 650 & \\
\hline & Abstynenci & $45 \%$ & $55 \%$ & $p<0.001$ & $39 \%$ & $61 \%$ & $p<0.001$ & $36 \%$ & $65 \%$ & $<0.001$ \\
\hline & Drinkers & 2305 & 3771 & 884 & 1474 & 2650 & 3488 & 835 & 1771 & 7567 \\
\hline Poland & Pijący & $38 \%$ & $62 \%$ & 8.84 & $36 \%$ & $64 \%$ & 34.00 & $32 \%$ & $68 \%$ & 75.01 \\
\hline Polska & Abstainers & 543 & 738 & & 1374 & 1859 & & 2013 & 2738 & \\
\hline & Abstynenci & $42 \%$ & $58 \%$ & & $43 \%$ & $58 \%$ & & $42 \%$ & $58 \%$ & \\
\hline & Drinkers & 1171 & 1670 & & 723 & 1191 & & 505 & 923 & \\
\hline Sweden & Pijący & $41 \%$ & $59 \%$ & 57.37 & $38 \%$ & $62 \%$ & 71.9 & $35 \%$ & $65 \%$ & 77.15 \\
\hline Szwecja & Abstainers & 362 & 264 & & 810 & 743 & & 1028 & 1011 & \\
\hline & Abstynenci & $58 \%$ & $42 \%$ & $p<0.001$ & $52 \%$ & $48 \%$ & $p<0.001$ & $50 \%$ & $50 \%$ & $p<0.001$ \\
\hline & Drinkers & 2958 & 2437 & & 1946 & 1815 & & 1432 & 1571 & \\
\hline Ukraine & Pijący & $55 \%$ & $45 \%$ & 16.43 & $52 \%$ & $48 \%$ & 64.3 & $48 \%$ & $52 \%$ & \\
\hline Ukraina & Abstainers & 752 & 477 & & 1764 & 1099 & & 2278 & 1343 & \\
\hline & Abstynenci & $61 \%$ & $39 \%$ & & $62 \%$ & $38 \%$ & & $63 \%$ & $37 \%$ & \\
\hline
\end{tabular}

*2003

$p<0.01$ ), however the relationship with alcohol consumption in the previous 30 days $(p<0.001-$ $p<0.05)$ and with binge drinking occured in every single analysed country $(p<0.001-p<0.01)$ (Table $\mathrm{X}$ ). In turn, the relationship between high risk assessment of consumption of small amounts of alcohol and drinking in the previous 12 months were recorded only in Italy and Ukraine $(p<0.001-p<0.01)$. The relationship with $(p<0,001-p<0,01)$, jednak związek $\mathrm{z}$ konsumpcją alkoholu w ciągu ostatnich $30 \mathrm{dni}(p<0,001-$ $p<0,05)$ oraz z upijaniem się wystąpił w każdym $\mathrm{Z}$ analizowanych krajów $(p<0,001-p<0,01)$ (tab. X). Z kolei związek ocen wysokiego ryzyka spożywania niewielkich ilości alkoholu z piciem alkoholu w ciągu ostatnich 12 miesięcy został odnotowany jedynie we Włoszech i na Ukrainie $(p<0,001-p<0,01)$. Związek z piciem w ciągu 
Table XII. Low and high risk perception of frequently drinking small amounts of alcohol and abstinence in the previous 12 months, 30 days and binge drinking (2015) $\left(\chi^{2}\right)$

Tabela XII. Związek niskiej i wysokiej percepcji ryzyka częstego spożywania niewielkich ilości alkoholu i abstynencji w ciągu 12 miesięcy i 30 dni przed badaniem oraz upijania się (2015) $\left(\chi^{2}\right)$

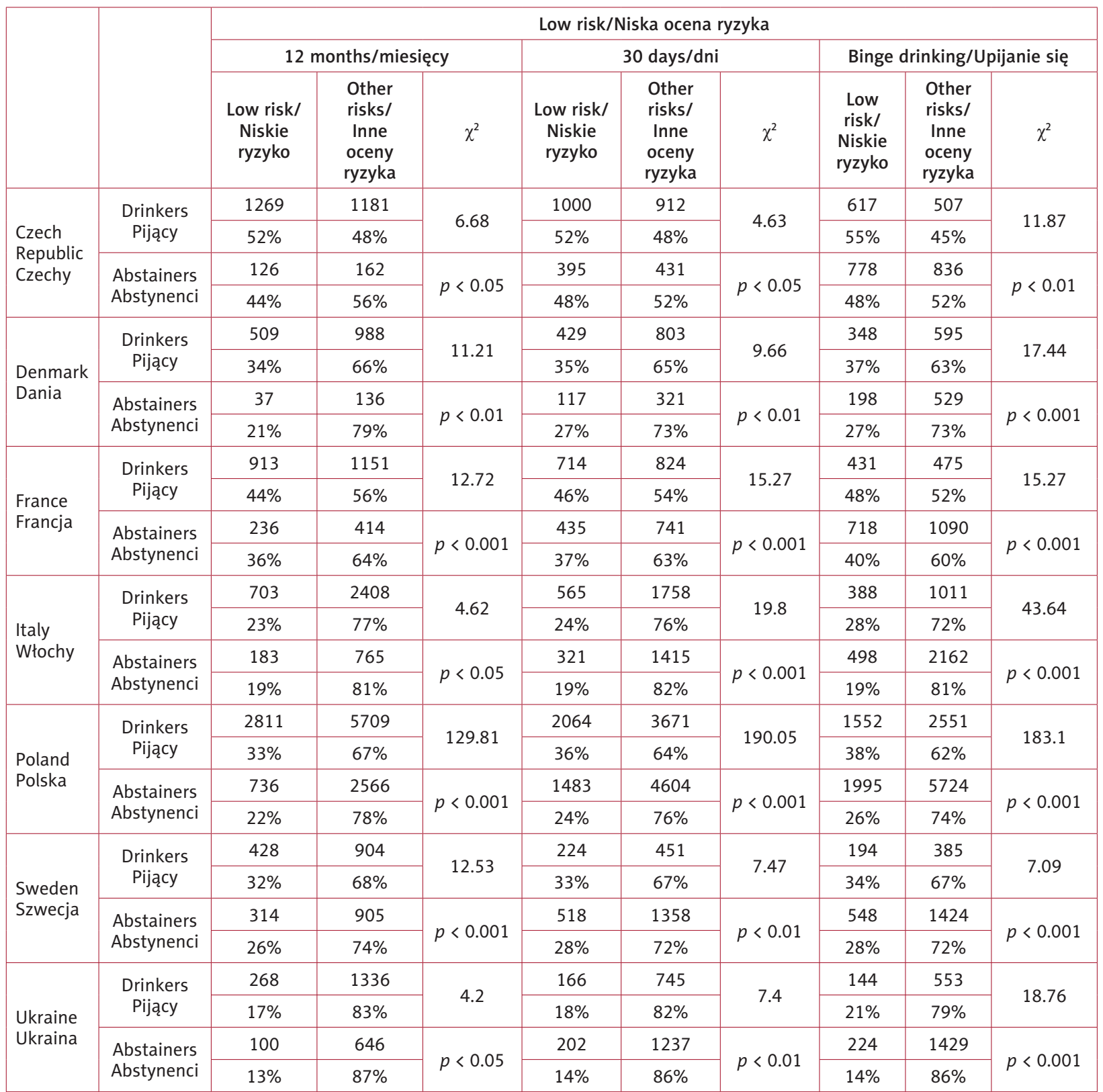

drinking in the previous 30 days occurred in Poland, in Italy and Ukraine $(p<0.001-p<0.01)$, with binge drinking in most countries $(p<0.001-$ $p<0.01$ ), except for Denmark and Sweden. Regarding the relation of binge drinking and perception of this behaviour, it was more uniform both in the case of low and high risk assessments and was recorded in all countries $(p<0.001)$ (Table XI). Similar situation took place with respect to con- ostatnich 30 dni wystąpił w Polsce, we Włoszech i na Ukrainie $(p<0,001-p<0,01)$, a z upijaniem się - w większości krajów $(p<0,001-p<0,01)$, z wyjątkiem Danii i Szwecji. Jeśli chodzi o związek upijania się oraz percepcji ryzyka tego zachowania, to zarówno w przypadku niskich, jak i wysokich ocen ryzyka był on bardziej jednolity - został odnotowany we wszystkich krajach $(p<0,001)$ (tab. XI). Podobna sytuacja miała 
Table XII. Continued

Tabela XII. Ciąg dalszy

\begin{tabular}{|c|c|c|c|c|c|c|c|c|c|c|}
\hline & & \multicolumn{9}{|c|}{ High risk/Wysoka ocena ryzyka } \\
\hline & & \multicolumn{3}{|c|}{12 months/miesięcy } & \multicolumn{3}{|c|}{30 days/dni } & \multicolumn{3}{|c|}{ Binge drinking/Upijanie się } \\
\hline & & $\begin{array}{c}\text { High risk/ } \\
\text { Wysokie } \\
\text { ryzyko }\end{array}$ & $\begin{array}{l}\text { Other } \\
\text { risks/ } \\
\text { Inne } \\
\text { oceny } \\
\text { ryzyka }\end{array}$ & $\chi^{2}$ & $\begin{array}{c}\text { High risk/ } \\
\text { Wysokie } \\
\text { ryzyko }\end{array}$ & $\begin{array}{l}\text { Other } \\
\text { risks/ } \\
\text { Inne } \\
\text { oceny } \\
\text { ryzyka }\end{array}$ & $\chi^{2}$ & $\begin{array}{c}\text { High } \\
\text { risk/ } \\
\text { Wysokie } \\
\text { ryzyko }\end{array}$ & $\begin{array}{l}\text { Other } \\
\text { risks/ } \\
\text { Inne } \\
\text { oceny } \\
\text { ryzyka }\end{array}$ & $\chi^{2}$ \\
\hline \multirow{4}{*}{$\begin{array}{l}\text { Czech } \\
\text { Republic } \\
\text { Czechy }\end{array}$} & \multirow{2}{*}{$\begin{array}{l}\text { Drinkers } \\
\text { Pijący }\end{array}$} & 265 & 2185 & \multirow{2}{*}{-} & 196 & 1716 & \multirow{2}{*}{-} & 115 & 1009 & \multirow{2}{*}{-} \\
\hline & & $11 \%$ & $89 \%$ & & $10 \%$ & $90 \%$ & & $10 \%$ & $90 \%$ & \\
\hline & \multirow{2}{*}{$\begin{array}{l}\text { Abstainers } \\
\text { Abstynenci }\end{array}$} & 30 & 258 & \multirow{2}{*}{-} & 99 & 727 & \multirow{2}{*}{-} & 180 & 1434 & \multirow{2}{*}{-} \\
\hline & & $10 \%$ & $90 \%$ & & $12 \%$ & $88 \%$ & & $11 \%$ & $89 \%$ & \\
\hline \multirow{4}{*}{$\begin{array}{l}\text { Denmark } \\
\text { Dania }\end{array}$} & \multirow{2}{*}{$\begin{array}{l}\text { Drinkers } \\
\text { Pijący }\end{array}$} & 235 & 1262 & \multirow{2}{*}{13.14} & 191 & 1041 & \multirow{2}{*}{5.88} & 156 & 787 & \multirow{2}{*}{-} \\
\hline & & $16 \%$ & $84 \%$ & & $16 \%$ & $85 \%$ & & $17 \%$ & $84 \%$ & \\
\hline & \multirow{2}{*}{$\begin{array}{l}\text { Abstainers } \\
\text { Abstynenci }\end{array}$} & 46 & 127 & \multirow{2}{*}{$p<0.001$} & 90 & 348 & \multirow{2}{*}{$p<0.05$} & 125 & 602 & \multirow{2}{*}{-} \\
\hline & & $27 \%$ & $73 \%$ & & $21 \%$ & $80 \%$ & & $17 \%$ & $83 \%$ & \\
\hline \multirow{4}{*}{$\begin{array}{l}\text { France } \\
\text { Francja }\end{array}$} & \multirow{2}{*}{$\begin{array}{l}\text { Drinkers } \\
\text { Pijący }\end{array}$} & 255 & 1809 & \multirow{2}{*}{6.2} & 190 & 1348 & \multirow{2}{*}{-} & 111 & 795 & \multirow{2}{*}{-} \\
\hline & & $12 \%$ & $88 \%$ & & $12 \%$ & $88 \%$ & & $12 \%$ & $88 \%$ & \\
\hline & \multirow{2}{*}{$\begin{array}{l}\text { Abstainers } \\
\text { Abstynenci }\end{array}$} & 105 & 545 & $n<005$ & 170 & 1006 & - & 249 & 1559 & \\
\hline & & $16 \%$ & $84 \%$ & $p<0.05$ & $15 \%$ & $86 \%$ & - & $14 \%$ & $86 \%$ & - \\
\hline & Drinkers & 1000 & 2111 & & 695 & 1628 & & 403 & 996 & \\
\hline Italy & Pijący & $32 \%$ & $68 \%$ & 13.10 & $30 \%$ & $70 \%$ & & $29 \%$ & $71 \%$ & 22.24 \\
\hline Włochy & Abstainers & 365 & 583 & & 670 & 1066 & & 962 & 1698 & \\
\hline & Abstynenci & $39 \%$ & $62 \%$ & 0.001 & $39 \%$ & $61 \%$ & .001 & $36 \%$ & $64 \%$ & 0.001 \\
\hline & Drinkers & 2165 & 6355 & 105 & 1357 & 4378 & 7056 & 924 & 3179 & 606 \\
\hline Poland & Pijący & $25 \%$ & $75 \%$ & 49.5 & $24 \%$ & $76 \%$ & 10.50 & $23 \%$ & $78 \%$ & .0 \\
\hline Polska & Abstainers & 1051 & 2251 & $n$ & 1859 & 4228 & & 2292 & 5427 & 1 \\
\hline & Abstynenci & $32 \%$ & $68 \%$ & .001 & $31 \%$ & $70 \%$ & & $30 \%$ & $70 \%$ & .001 \\
\hline & Drinkers & 267 & 1065 & & 118 & 557 & 710 & 112 & 467 & \\
\hline Sweden & Pijący & $20 \%$ & $80 \%$ & & $18 \%$ & $83 \%$ & 1.10 & $19 \%$ & $81 \%$ & - \\
\hline Szwecja & Abstainers & 271 & 948 & & 420 & 1456 & 01 & 426 & 1546 & \\
\hline & Abstynenci & $22 \%$ & $78 \%$ & - & $22 \%$ & $78 \%$ & 0.01 & $22 \%$ & $78 \%$ & - \\
\hline & Drinkers & 675 & 929 & & 369 & 542 & & 273 & 424 & 521 \\
\hline Ukraine & Pijący & $42 \%$ & $58 \%$ & - & $41 \%$ & $60 \%$ & - & $39 \%$ & $61 \%$ & 5.24 \\
\hline Ukraina & Abstainers & 330 & 416 & & 636 & 803 & & 732 & 921 & \\
\hline & Abstynenci & $44 \%$ & $56 \%$ & - & $44 \%$ & $56 \%$ & - & $44 \%$ & $56 \%$ & \\
\hline
\end{tabular}

suming alcohol within the previous 12 months $(p<0.001-p<0.05)$ and 30 days $(p<0.001)$.

Twenty years later, in 2015, the relationship between assessments of low risk of frequent consumption of small amounts of alcohol and drinking alcohol in the previous 12 months, the previous 30 days and binge drinking was recorded in all studied countries $(p<0.001-p<0.05)$ (Table XII). In turn, the association between perceived high miejsce $\mathrm{w}$ odniesieniu do picia alkoholu w ciągu 12 miesięcy $(p<0,001-p<0,05)$ i 30 dni $(p<0,001)$.

Dwadzieścia lat później, w 2015 roku związek ocen niskiego ryzyka częstego spożywania niewielkich ilości alkoholu i sięgania po alkohol w ciągu ostatnich 12 miesięcy, 30 dni oraz upijania się został odnotowany we wszystkich krajach $(p<0,001-p<0,05)$ (tab. XII). Z kolei związek 
Table XIII. Low and high risk perception of binge drinking and abstinence in the previous 12 months, 30 days and binge drinking (2015) $\left(\chi^{2}\right)$

Tabela XIII. Związek niskiej i wysokiej percepcji ryzyka upijania się i abstynencji w ciągu 12 miesięcy i 30 dni przed badaniem oraz upijania się (2015) $\left(\chi^{2}\right)$

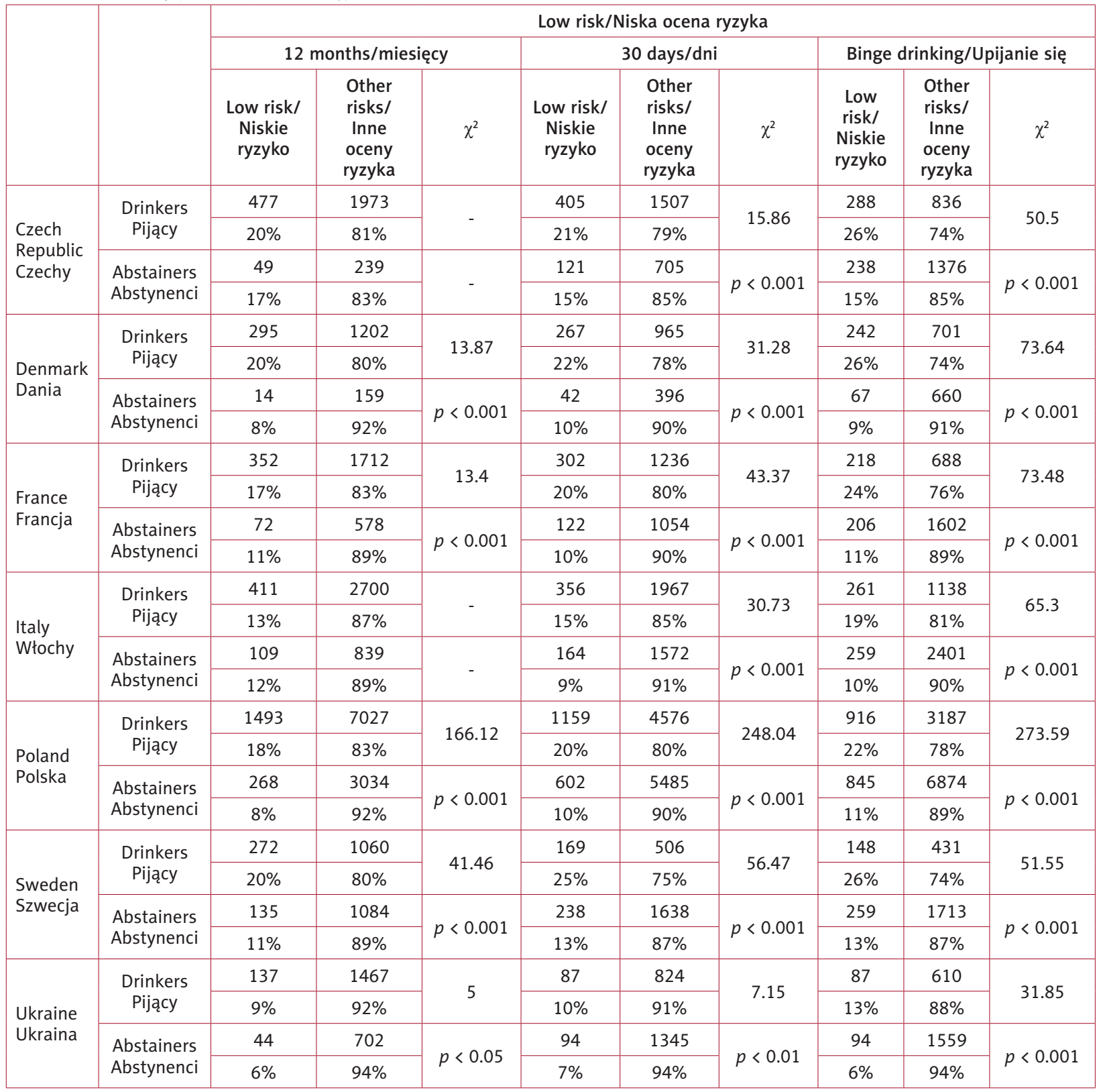

risk of frequent consumption of small amounts of alcohol and alcohol use in the previous 12 months was only recorded in some countries, e.g. in Poland, Denmark, France and Italy $(p<0.001-$ $p<0.05)$. The relationship with alcohol consumption in the previous 30 days occurred in Denmark, Poland, Sweden and Italy $(p<0.001-p<0.05)$, while the relationship with binge drinking was recorded in Poland, France and Ukraine $(p<0.001-$ $p<0.05)$. The final analysed phenomenon: the re- ocen wysokiego ryzyka częstego spożywania niewielkich ilości alkoholu i sięgania po alkohol w ciągu ostatnich 12 miesięcy został odnotowany tylko w części krajów, w tym w Polsce oraz Danii, Francji i we Włoszech $(p<0,001-p<0,05)$. Związek z piciem alkoholu w ciągu ostatnich $30 \mathrm{dni}$ wystąpił w Danii, Polsce, Szwecji i we Włoszech $(p<0,001-p<0,05)$, podczas gdy związek z upijaniem się został odnotowany w Polsce, Francji i na Ukrainie $(p<0,001-p<0,05)$. Ostatnie $\mathrm{z}$ anali- 
Table XIII. Continued

Tabela XIII. Ciąg dalszy

\begin{tabular}{|c|c|c|c|c|c|c|c|c|c|c|}
\hline & & \multicolumn{9}{|c|}{ High risk/Wysoka ocena ryzyka } \\
\hline & & \multicolumn{3}{|c|}{12 months/miesięcy } & \multicolumn{3}{|c|}{30 days/dni } & \multicolumn{3}{|c|}{ Binge drinking/Upijanie się } \\
\hline & & $\begin{array}{c}\text { High risk/ } \\
\text { Wysokie } \\
\text { ryzyko }\end{array}$ & $\begin{array}{c}\text { Other } \\
\text { risks/ } \\
\text { Inne } \\
\text { oceny } \\
\text { ryzyka }\end{array}$ & $\chi^{2}$ & $\begin{array}{l}\text { High risk/ } \\
\text { Wysokie } \\
\text { ryzyko }\end{array}$ & $\begin{array}{c}\text { Other } \\
\text { risks/ } \\
\text { Inne } \\
\text { oceny } \\
\text { ryzyka }\end{array}$ & $\chi^{2}$ & $\begin{array}{c}\text { High } \\
\text { risk/ } \\
\text { Wysokie } \\
\text { ryzyko }\end{array}$ & $\begin{array}{l}\text { Other } \\
\text { risks/ } \\
\text { Inne } \\
\text { oceny } \\
\text { ryzyka }\end{array}$ & $\chi^{2}$ \\
\hline \multirow{4}{*}{$\begin{array}{l}\text { Czech } \\
\text { Republic } \\
\text { Czechy }\end{array}$} & \multirow{2}{*}{$\begin{array}{l}\text { Drinkers } \\
\text { Pijący }\end{array}$} & 862 & 1588 & \multirow{2}{*}{6.33} & 636 & 1276 & \multirow{2}{*}{20.23} & 333 & 791 & \multirow{2}{*}{33.37} \\
\hline & & $35 \%$ & $65 \%$ & & $33 \%$ & $67 \%$ & & $30 \%$ & $70 \%$ & \\
\hline & \multirow{2}{*}{$\begin{array}{l}\text { Abstainers } \\
\text { Abstynenci }\end{array}$} & 123 & 165 & \multirow{2}{*}{$p<0.05$} & 349 & 477 & \multirow{2}{*}{$p<0.001$} & 652 & 962 & \multirow{2}{*}{$p<0.001$} \\
\hline & & $43 \%$ & $57 \%$ & & $42 \%$ & $58 \%$ & & $40 \%$ & $60 \%$ & \\
\hline \multirow{4}{*}{$\begin{array}{l}\text { Denmark } \\
\text { Dania }\end{array}$} & \multirow{2}{*}{$\begin{array}{l}\text { Drinkers } \\
\text { Pijący }\end{array}$} & 531 & 966 & \multirow{2}{*}{43.75} & 396 & 836 & \multirow{2}{*}{71.69} & 268 & 675 & \multirow{2}{*}{86.81} \\
\hline & & $36 \%$ & $65 \%$ & & $32 \%$ & $68 \%$ & & $28 \%$ & $72 \%$ & \\
\hline & \multirow{2}{*}{$\begin{array}{l}\text { Abstainers } \\
\text { Abstynenci }\end{array}$} & 106 & 67 & \multirow{2}{*}{$p<0.001$} & 241 & 197 & \multirow{2}{*}{$p<0.001$} & 369 & 358 & \multirow{2}{*}{$p<0.001$} \\
\hline & & $61 \%$ & $39 \%$ & & $55 \%$ & $45 \%$ & & $51 \%$ & $49 \%$ & \\
\hline \multirow{4}{*}{$\begin{array}{l}\text { France } \\
\text { Francja }\end{array}$} & \multirow{2}{*}{$\begin{array}{l}\text { Drinkers } \\
\text { Pijący }\end{array}$} & 904 & 1160 & \multirow{2}{*}{31.07} & 605 & 933 & \multirow{2}{*}{79.29} & 317 & 589 & \multirow{2}{*}{76.13} \\
\hline & & $44 \%$ & $56 \%$ & & $39 \%$ & $61 \%$ & & $35 \%$ & $65 \%$ & \\
\hline & \multirow{2}{*}{$\begin{array}{l}\text { Abstainers } \\
\text { Abstynenci }\end{array}$} & 366 & 284 & $n, \cap \cap 01$ & 665 & 511 & & 953 & 855 & \\
\hline & & $56 \%$ & $44 \%$ & $p<0.001$ & $57 \%$ & $44 \%$ & 0.001 & $53 \%$ & $47 \%$ & 01 \\
\hline & Drinkers & 1614 & 1497 & & 1127 & 1196 & & 600 & 799 & 7 \\
\hline Italy & Pijący & $52 \%$ & $48 \%$ & 10.01 & $49 \%$ & $52 \%$ & 50.00 & $43 \%$ & $57 \%$ & 90.01 \\
\hline Włochy & Abstainers & 562 & 386 & & 1049 & 687 & & 1576 & 1084 & \\
\hline & Abstynenci & $59 \%$ & $41 \%$ & 001 & $60 \%$ & $40 \%$ & & $59 \%$ & $41 \%$ & 0.001 \\
\hline & Drinkers & 3575 & 4945 & & 2239 & 3496 & & 1513 & 2590 & 098 \\
\hline Poland & Pijący & $42 \%$ & $58 \%$ & 170.00 & $39 \%$ & $61 \%$ & 210.05 & $37 \%$ & $63 \%$ & 209.0 \\
\hline Polska & Abstainers & 1861 & 1441 & 101 & 3197 & 2890 & 1 & 3923 & 3796 & 1 \\
\hline & Abstynenci & $56 \%$ & $44 \%$ & $p$ & $53 \%$ & $48 \%$ & & $51 \%$ & $49 \%$ & 01 \\
\hline & Drinkers & 524 & 808 & & 241 & 434 & & 195 & 384 & 3571 \\
\hline Sweden & Pijący & $39 \%$ & $61 \%$ & 30.42 & $36 \%$ & $64 \%$ & & $34 \%$ & $66 \%$ & 1 \\
\hline Szwecja & Abstainers & 612 & 607 & & 895 & 981 & & 941 & 1031 & \\
\hline & Abstynenci & $50 \%$ & $50 \%$ & 0.001 & $48 \%$ & $52 \%$ & & $48 \%$ & $52 \%$ & 01 \\
\hline & Drinkers & 975 & 629 & 492 & 533 & 378 & 91 & 375 & 322 & \\
\hline Ukraine & Pijący & $61 \%$ & $39 \%$ & 4.92 & $59 \%$ & $42 \%$ & 9.1 & $54 \%$ & $46 \%$ & \\
\hline Ukraina & Abstainers & 489 & 257 & & 931 & 508 & & 1089 & 564 & \\
\hline & Abstynenci & $66 \%$ & $35 \%$ & & $65 \%$ & $35 \%$ & & $66 \%$ & $34 \%$ & 001 \\
\hline
\end{tabular}

lationship between risk assessment of binge drinking and drinking and binge drinking was recorded in most countries (Table XIII). However, in the case of low risk assessments, there was no impact on alcohol consumption in the previous 12 months in the Czech Republic and Italy. zowanych zjawisk - związek ocen ryzyka upijania się i sięgania po alkohol oraz upijania się - został odnotowany w większości krajów (tab. XIII), jednak w przypadku niskich ocen ryzyka nie odnotowano wpływu na picie alkoholu w ciągu ostatnich 12 miesięcy w Czechach i we Włoszech. 


\section{- Discussion}

In the 20-year period between 1995 and 2015, the percentage of students who consumed alcohol decreased in the majority of the analysed countries, after significant increase in the 1990s. The declining trend in the consumption of alcoholic beverages among young people is a phenomenon observed in most European countries, as evidenced both by the results of ESPAD [37] and HBSC studies [38]. Trends in binge drinking are more diverse, especially when considering the period between the last two ESPAD editions.

Changes in perception of alcohol-related risks did not always correspond to consumption trends. Between 1995 and 2015, the percentage of students who assessed frequent consumption of small amounts of alcohol as low-risk or no-risk behaviour increased in Poland, the Czech Republic and Sweden. In these countries, the percentage of students assessing this behaviour as highly risky also consistently decreased. The turning point for countries where low risk ratings declined initially was in 2011: between 2011 and 2015, an upward trend was clearly visible in all countries, while the percentage of students who perceived frequent consumption of small amounts of alcohol as highly risky decreased. Changes in young people's perceptions of binge drinking were less dramatic. Between 1995 and 2015, the number of students assessing binge drinking as a low-risk behaviour decreased in some of the analysed countries (Denmark, Italy, Ukraine). Concurrently, the percentage of students who rated binge drinking as a high-risk behaviour increased in the majority of the studied countries.

Regarding the aforementioned changes in risk perception of frequent consumption of small amounts of alcohol between 2011 and 2015, it is worth pointing out that during this period the percentage of students assessing binge drinking as a highly risky behaviour increased in only some of the studied countries (Poland, Denmark, France, Italy).

The relationship between risk perception and alcohol use changed over time, but these changes depended on the analysed pattern of consumption. Both in 1995 and in 2015, in every studied country, low risk assessment of binge drinking was associated with binge drinking and having drank alcohol in the previous 30 days, while high risk assessments were associated with avoiding such behaviours.

\section{- OmóWIenie}

W ciągu 20 lat, między rokiem 1995 a 2015, w większości analizowanych krajów, po znacznych wzrostach w latach 90., zmniejszył się odsetek uczniów sięgających po alkohol. Spadkowy trend w konsumpcji napojów alkoholowych wśród młodzieży jest zjawiskiem odnotowywanym w większości krajów europejskich, czego dowodzą zarówno wyniki badań ESPAD [37], jak i HBSC [38]. Trendy w upijaniu się są bardziej zróżnicowane, szczególnie biorąc pod uwagę okres pomiędzy dwoma ostatnimi pomiarami badań ESPAD.

Zmiany w percepcji ryzyka związanego $\mathrm{z}$ alkoholem nie zawsze korespondowały $\mathrm{z}$ trendami konsumpcji. W latach 1995-2015 odsetek uczniów, którzy oceniali częste spożywanie niewielkich ilości alkoholu jako zachowanie mało ryzykowne bądź pozbawione ryzyka zwiększał się w Polsce, w Czechach i w Szwecji. W tych krajach konsekwentnie malał również odsetek uczniów oceniających to zachowanie jako wysoce ryzykowne. Punkt zwrotny dla krajów, w których początkowo notowano spadki ocen niskiego ryzyka, to rok 2011: w latach 2011-2015 we wszystkich krajach wyraźnie zarysował się trend wzrostowy, podczas gdy odsetek uczniów, którzy postrzegali częste spożywanie małych ilości alkoholu jako wysoce ryzykowne - malał. Zmiany percepcji ryzyka upijania się miały mniej gwałtowny przebieg. W latach 1995-2015 w części analizowanych krajów (Dania, Włochy, Ukraina) nastąpił spadek liczby uczniów oceniających upijanie się jako zachowanie o niskim stopniu ryzyka. Jednocześnie w większości krajów nastąpił wzrost odsetka uczniów, którzy oceniali upijanie się jako zachowanie o wysokim stopniu ryzyka.

W kontekście przywołanych powyżej zmian percepcji ryzyka częstego spożywania niewielkich ilości alkoholu w latach 2011-2015 warto zauważyć, że w tym okresie jedynie w części krajów (Polska, Dania, Francja, Włochy) wzrastał odsetek uczniów oceniających upijanie się jako zachowanie wysoce ryzykowne.

Związek percepcji ryzyka i sięgania po alkohol zmieniał się w czasie, zmiany te zależały jednak od analizowanego wzoru konsumpcji. Zarówno w roku 1995, jak i 2015, w każdym z krajów niskie oceny ryzyka upijania się wiązały się z upijaniem się oraz sięganiem po alkohol $\mathrm{w}$ ciągu ostatnich $30 \mathrm{dni}$, podczas gdy wysokie oceny ryzyka wiązały się z unikaniem takich zachowań. Postrzeganie 
The risk perception of frequent consumption of small amounts of alcohol was more diverse. In 1995, an association of high risk assessments for frequent consumption of small amounts of alcohol and abstinence took place only in Italy and Ukraine. In 2015 it was noted in Poland, Denmark, Italy and France. An association between high risk assessment for frequent consumption of small amounts of alcohol and drinking in the previous 30 days in both 1995 and 2015 occurred in some of the analysed countries: these included Poland and Italy. The association of high risk assessment of frequent consumption of small amounts of alcohol and binge drinking has diminished with time: in 1995 it was recorded in most countries besides Denmark and Sweden, but in 2015 it only occurred in Poland, Ukraine and France.

The assessment of changes in risk perception is not unambiguous over time. Taking into account trends in 1995 and 2015, a lower proportion of students consuming alcohol may or may not be associated with an increase in high risk ratings or a decrease in low risk assessments. In the Czech Republic and Poland, the decrease in the number of drinkers in the previous 12 months was linked with a decrease of the percentage of high risk assessments and an increase in the low risk assessment of frequent alcohol consumption of small amounts. In Denmark, the decline in the number of consumers was not related to the increase in high-risk ratings, and in France the increase in the percentage of drinkers in the previous 30 days was associated only with a decrease of low risk assessment of frequent consumption of small amounts of alcohol. A similar trend can be observed in the risk perception associated with binge drinking: in Sweden, the drop in the percentage of students who binge drink was not related to the change in risk assessment of this behaviour. The increase in the number of binge drinkers in the Czech Republic corresponded with the decline in high risk assessments of binge drinking, it had no impact on low risk assessments however. Compared to other European countries, Poland is characterised by a significant impact of individual risk perception on alcohol consumption: along with an increase in risk perception, young people used alcohol less often and less often got drunk.

Differences in risk perception and the impact of risk perception on alcohol consumption may result from cultural determinants and normalisation of alcohol consumption, first and fore- ryzyka częstego spożywania niewielkich ilości alkoholu było bardziej zróżnicowane. W 1995 roku związek wysokich ocen ryzyka częstego spożywania niewielkich ilości alkoholu i abstynencji pojawił się jedynie we Włoszech i na Ukrainie, podczas gdy w 2015 roku został odnotowany w Polsce, Danii, Włoszech oraz we Francji. Związek wysokich ocen ryzyka częstego spożywania niewielkich ilości alkoholu oraz picia w ciągu ostatnich $30 \mathrm{dni}$ wystąpił w części analizowanych krajów, w tym w Polsce i we Włoszech zarówno w roku 1995, jak i 2015. Podczas gdy związek wysokich ocen ryzyka częstego spożywania niewielkich ilości alkoholu i upijania z czasem zanikał, w 1995 został odnotowany w większości krajów, poza Danią i Szwecją, lecz w 2015 roku wystąpił jedynie w Polsce, na Ukrainie oraz we Francji.

Ocena zmian percepcji ryzyka w czasie nie jest jednoznaczna. Biorąc pod uwagę trendy z lat 1995 i 2015, ograniczenie odsetka uczniów sięgających po alkohol może, lecz nie musi, wiązać się ze wzrostem wysokich ocen ryzyka bądź spadkiem niskich ocen ryzyka. W Czechach i w Polsce spadek liczby pijących w ciągu 12 miesięcy wiązał się ze spadkiem wysokich ocen ryzyka oraz wzrostem odsetka niskich ocen ryzyka częstego spożywania niewielkich ilości alkoholu. W Danii spadek liczby konsumentów nie miał związku ze wzrostem ocen wysokiego ryzyka, a we Francji wzrost odsetka pijących w ciągu ostatnich 30 dni wiązał się jedynie ze spadkiem niskich ocen ryzyka częstego spożywania niewielkich ilości alkoholu. Podobną tendencję można zaobserwować w przypadku percepcji ryzyka związanego $\mathrm{z}$ upijaniem się: w Szwecji spadek odsetka uczniów, którzy upijali się nie miał związku ze zmianą ocen ryzyka tego zachowania, a wzrost liczby uczniów upijających się w Czechach korespondował ze spadkiem wysokich ocen ryzyka upijania się, nie miał jednak wpływu na niskie oceny ryzyka. $\mathrm{Na}$ tle pozostałych krajów europejskich Polska odznacza się znaczącym wpływem indywidualnej percepcji ryzyka na picie alkoholu - wraz ze wzrostem percepcji ryzyka, młodzież rzadziej sięgała po alkohol i rzadziej się upijała.

Różnice w percepcji ryzyka oraz we wpływie percepcji ryzyka na konsumpcję alkoholu mogą wynikać z uwarunkowań kulturowych oraz normalizacji konsumpcji alkoholu, w tym przede wszystkim popularyzacji wzoru umiarkowanej 
most, the popularisation of the moderate alcohol consumption pattern. This could form a contrast with risky consumption, characterised by drinking large amounts of alcohol per occasion [39]. A result of this could be an increase of the percentage of students assessing the risk of moderate consumption as low in recent years in all of the analysed countries. Changes in risk perception could also be attributed to effective education about alcohol related risk, because young people may have a tendency to overestimate the actual risk [9]. The effectiveness of activities related to risk comunication which are based on reliable knowledge and influencing attitudes, may partially explain the lack of impact of risk perception on alcohol consumption in Sweden, in particular with regard to high risk assessments [9]. On the other hand, cultural conditions and liberal alcohol policy may affect the weak associations of risk perception and alcohol consumption, among others, in Denmark and the Czech Republic [30]. The degree of restrictiveness of alcohol policy [34] had an indirect impact on risk perception: a lack of connection between risk perception and alcohol consumption was noted in countries with both high (Sweden) and low (Czech Republic, Denmark) levels of alcohol policy restrictions. However, there was somewhat of a connection in countries with moderate restrictiveness (France, Italy).

To sum up, it can be concluded that risk perception is associated with drinking or abstaining from alcohol, and the association is stronger in the case of risk of binge drinking. This mechanism occurs in most of the countries covered by this analysis, both in the case of low and high risk assessments. This indicates a broad tendency to perceive threats regarding being intoxicated, but ignoring the remaining dangers associated with alcohol consumption.

\section{- Conclusions}

Risk assessments change over time. In the same countries risk assessment regarding alcohol consumption may change over the years or it may also remain unaffected. This indicates that the relationship between risk perception and alcohol consumption occurs recurrently. It may partially explain the limited effectiveness of prevention measures aimed at increasing knowledge and risk awareness, and may suggest the need to review them. konsumpcji alkoholu, stawianej $\mathrm{w}$ opozycji do konsumpcji ryzykownej, cechującej się wypijaniem dużych ilości alkoholu przy jednej okazji [39]. Efektem tego może być obserwowany $\mathrm{w}$ ciągu ostatnich lat $\mathrm{w}$ każdym $\mathrm{z}$ analizowanych krajów wzrost odsetka uczniów oceniających ryzyko umiarkowanej konsumpcji jako niskie. Zmiany percepcji ryzyka mogą również wiązać się ze skuteczną edukacją na temat ryzyka związanego $\mathrm{z}$ alkoholem, ponieważ młodzież może mieć tendencję do przeceniania ryzyka [9]. Skuteczność działań związanych z komunikacją ryzyka, opartych na rzetelnej wiedzy i wpływających na postawy, może do pewnego stopnia tłumaczyć brak wpływu percepcji ryzyka na konsumpcję alkoholu w Szwecji, szczególnie w odniesieniu do wysokich ocen ryzyka [9]. Z drugiej strony - uwarunkowania kulturowe i liberalna polityka wobec alkoholu mogą wpływać na słabe związki percepcji ryzyka i konsumpcji alkoholu, m.in. w Danii i Czechach [30]. Stopień restrykcyjności polityki alkoholowej [34] miał pośredni wpływ na percepcję ryzyka - brak związku percepcji ryzyka i konsumpcji alkoholu został odnotowany zarówno w krajach o wysokim (Szwecja), jak i niskim (Czechy, Dania) poziomie restrykcyjności polityki wobec alkoholu, jednak częściowo wystąpił w krajach o umiarkowanej restrykcyjności (Francja, Włochy).

Podsumowując, można stwierdzić, że percepcja ryzyka wiąże się z piciem alkoholu bądź abstynencją, przy czym związek ten jest silniejszy w przypadku ryzyka upijania się. Mechanizm ten występuje w większości krajów objętych niniejszą analizą, zarówno w przypadku niskich, jak i wysokich ocen ryzyka, co świadczy o szerokiej tendencji do postrzegania zagrożeń w kategoriach osiągania stanu nietrzeźwości, lecz ignorowaniu pozostałych niebezpieczeństw związanych z piciem alkoholu.

\section{- WNIOSKI}

Oceny ryzyka zmieniają się $\mathrm{w}$ czasie. W tych samych krajach oceny ryzyka związanego z konsumpcją alkoholu mogą różnić się na przestrzeni lat, mogą również pozostać niezmienione - świadcząc o okresowym występowaniu związku percepcji ryzyka i konsumpcji alkoholu, co może do pewnego stopnia wyjaśniać ograniczoną skuteczność narzędzi profilaktyki skierowanej na podniesienie wiedzy i świadomości ryzyka oraz sugerować potrzebę ich rewizji. 
Taking into account the changes in recent years, both in Poland and other European countries, one can point to three basic conclusions related to risk perception of frequent consumption of small amounts of alcohol:

1. A high perceived risk of this consumption pattern is more often associated with abstinence than in the case of low risk assessments and has a clear impact on current alcohol consumption.

2. In recent years, frequent consumption of small amounts of alcohol ceased to be perceived as a health hazard, and its relation to binge drinking is less frequent.

3. Risk perception may have a limited effect on alcohol use and binge drinking in countries with liberal as well as restrictive alcohol policies.

One of the issues that prevention aimed towards young people will undoubtedly have to face in the coming years is the phenomenon of frequent consumption of small amounts of alcohol. The increase in popularity of this consumption pattern among adults (so-called moderate consumption) could be a key factor in shaping alcohol consumption patterns among young people. Existing recommendations for safe alcohol consumption for adults are not intended for adolescents [40], and their knowledge among youth is limited [41]. Developing recommendations specifically for youths therefore may prove necessary to reduce alcohol-harm in this age group. This could also be supported by educating school children about "risk cultures", together with an appropriate, reliable, evidence-based message about alcohol related risk, aimed at shaping attitudes and creating trust in public institutions and public health initiatives.
Biorąc pod uwagę zmiany dokonujące się w ostatnich latach, zarówno w Polsce, jak i w pozostałych krajach europejskich, można wskazać na trzy zasadnicze wnioski związane $\mathrm{z}$ zagadnieniami percepcji ryzyka częstej konsumpcji niewielkich ilości alkoholu:

1. Wysokie ryzyko tego wzoru konsumpcji częściej wiążę się $\mathrm{z}$ abstynencją niż w przypadku niskich ocen ryzyka, i ma wyraźny wpływ na bieżącą konsumpcję alkoholu.

2. W ciągu ostatnich lat częsta konsumpcja niewielkich ilości alkoholu przestaje być postrzegana $\mathrm{w}$ kategoriach zagrożenia dla zdrowia, a jej związek $\mathrm{z}$ upijaniem się występuje rzadziej.

3. Percepcja ryzyka może mieć ograniczony wpływ na picie alkoholu i upijanie się zarówno w krajach o liberalnej, jak i restrykcyjnej polityce wobec alkoholu.

Zjawisko częstej konsumpcji niewielkich ilości alkoholu jest niewątpliwie jednym z zagadnień, $\mathrm{z}$ którymi będzie musiała zmierzyć się $\mathrm{w}$ najbliższych latach profilaktyka adresowana do młodzieży. Wzrost popularności tego wzoru konsumpcji wśród dorosłych (tzw. konsumpcja umiarkowana), może przełożyć się na zmiany w konsumpcji alkoholu wśród młodzieży. Istniejące rekomendacje bezpiecznej konsumpcji alkoholu dla osób dorosłych nie są przeznaczone dla niepełnoletnich [40], a ich znajomość wśród młodzieży jest ograniczona [41], dlatego rozwinięcie rekomendacji dla młodzieży może okazać się niezbędne $\mathrm{w}$ celu ograniczenia szkód związanych $\mathrm{z}$ alkoholem $\mathrm{w}$ tej grupie wiekowej. Będzie temu także sprzyjać pogłębianie wiedzy na temat „kultur ryzyka” wśród młodzieży szkolnej, wraz z odpowiednim, rzetelnym, opartym na dowodach naukowych przekazem dotyczącym ryzyka związanego $\mathrm{z}$ alkoholem, mającym na celu kształtowanie postaw oraz wzbudzanie zaufania wobec instytucji publicznych i działań na rzecz zdrowia publicznego.

\section{Conflict of interest/Konflikt interesów}

None declared./Nie występuje.

\section{Financial support/Finansowanie}

Ministry of Science and Higher Education, Core funding for statutory R \& D activities, no 501-002-15008/ 501-002-16008/ 501-002-117008./Ministerstwo Nauki i Szkolnictwa Wyższego, Temat statutowy, nr 501-002-15008/ 501-002-16008/ 501-002-117008. 


\section{Ethics/Etyka}

The work described in this article has been carried out in accordance with the Code of Ethics of the World Medical Association (Declaration of Helsinki) on medical research involving human subjects, EU Directive (210/63/EU) on protection of animals used for scientific purposes, Uniform Requirements for manuscripts submitted to biomedical journals and the ethical principles defined in the Farmington Consensus of 1997.

Treści przedstawione w pracy są zgodne z zasadami Deklaracji Helsińskiej odnoszącymi się do badań z udziałem ludzi, dyrektywami UE dotyczącymi ochrony zwierząt używanych do celów naukowych, ujednoliconymi wymaganiami dla czasopism biomedycznych oraz z zasadami etycznymi określonymi w Porozumieniu z Farmington w 1997 roku.

\section{References/Piśmiennictwo}

1. Ferrer R, Klein WM. Risk perceptions and health behaviour. Current Opinion in Psycho$\log y 2015 ; 5: 85-9$.

2. Slovic P. Perception of risk. Science 1987; 236: 280-5.

3. Weinstein ND. Why it won't happen to me: Perceptions of risk factors and illness susceptibility. Health Psychol 1984; 3: 434-57.

4. Fishbein M, Ajzen I. Belief, attitude, intention, and behavior. Reading, MA: Addison-Wesley; 1975.

5. Ajzen I, Fishbein M. Understanding attitudes and predicting social behavior. Englewood Cliffs, NJ: Prentice-Hall; 1980.

6. Sjöberg L. Risk perception of alcohol consumption. Alcoholism: Clinical and Experimental Research 1998; 22: 277-84.

7. Sjöberg L. The methodology of risk perception research. Quality and Quantity 2000; 34 : 407-18.

8. Chomynova P, Miller P, Beck F. Perceived risks of alcohol and illicit drugs: Relation to prevalence of use on individual and country level. Journal of Substance Use 2009; 14 : 250-64.

9. Lundborg P, Lindgren B. Risk perceptions and alcohol consumption among young people. Journal of Risk and Uncertainty 2002; 25: 165-83.

10. Miller P, Chomcynova P, Beck F. Predicting teenage beliefs concerning the harm alcohol and cannabis use may do in eight European countries. Journal of Substance Use 2009; 14: $364-74$.

11. Hampson SE, Severson HH, Burns WJ, Slovic P, Fisher KJ. Risk perception, personality factors and alcohol use among adolescents. Personality and Individual Differences 2001; 30: 167-81.

12. Slovic P. Do adolescent smokers know the risks? Duke Law Journal 1998; 47: 1133-41.

13. Slovic P. The Perception of Risk. London: Earthscan Publications; 2000.

14. Rehm J, Room R, Taylor B. Method for moderation: Measuring the risk of alcohol-attributable mortality as a basis for drinking guidelines. International Journal of Methods in Psychiatric Research 2008; 17: 141-51.

15. Brown SL, Nowlan L, Taylor PJ, Morley AM. Fuzzy Risk Perception: Correlates of "Fuzzy" and Specific Measures of Outcome Likelihood in Young Drinkers. Journal of Experimental Psychology 2013; 19: 120-29.

16. Douglas M. Risk and blame: Essays in cultural theory. London: Routledge; 1992.

17. Douglas M. The depoliticization of risk. In: Ellis RJ, Thompson M (eds.). Culture Matters: Essays in Honor of Aaron Wildavsky. Boulder: Westview Press; 1987, 121-32.

18. Douglas M, Wildavsky A. Risk and Culture: An Essay on Selection of Technological and Environmental Dangers. Berkeley: California University Press; 1982.

19. Rayner S. Cultural theory and risk analysis. In: Krimsky S, Golding D (eds.). Social Theories of Risk. Westport: Praeger; 1992, 83-115.

20. Rayner S. Risk perception, technology acceptance, and institutional culture: case studies of some new definitions. In: Ruck B (ed.). Risk is a Construct. Munich: Knesebeck; 1993, 197-220. 
21. Thompson M, Ellis R, Wildavsky A. Cultural Theory. Boulder: Westview Press; 1990.

22. Lupton D. Risk as moral danger. The social and political functions of risk discourse in public health. International Journal of Health Services 1993; 23: 425-35.

23. Rippl S. Cultural theory and risk perception: a proposal for a better measurement. Journal of Risk Research 2002; 5: 147-65.

24. Boholm Å. Speaking of risk: Matters of context. Environmental Communication 2009; 3: $335-54$.

25. Grevenstein D, Nagy E, Kroeninger-Jungaberle H. Development of risk perception and substance use of tobacco, alcohol and cannabis among adolescents and emerging adults: Evidence of directional influences. Substance Use \& Misuse 2015; 50: 376-86.

26. Lejckova P, Csemy L. Risk perception and attitudes of young people towards drug use. 2005 (www.espad.org/file/125/download?token=oLpKqmpx) (available: 07.02.2018).

27. Chomynova P, Miller P, Beck F. Perceived risks of alcohol and illicit drugs: Relation to prevalence of use on individual and country level. Journal of Substance Use 2009; 14: 250-64.

28. Andersson B, Miller P, Beck F, Chomynova P. The prevalence of and perceived risks from drug use among teenagers in 33 European countries. Journal of Substance Use 2009; 3-4: 189-96.

29. Elekes Z, Miller P, Chomynova P, Beck F. Changes in perceived risk of different substance use by ranking order of drug attitudes in different ESPAD countries. Journal of Substance Use 2009; 3-4: 197-210.

30. Dzúrová D, Spilková J, Vraný M. Substance misuse and its risk perception in European teenagers. Children Geographies 2016; 14: 203-16.

31. Borucka A, Ostaszewski K. Koncepcja resilience. Kluczowe pojęcia i wybrane zagadnienia. Medycyna Wieku Rozwojowego 2008; 12: 587-97.

32. Ostaszewski K. Zachowania ryzykowne młodzieży w perspektywie mechanizmów resilience. Warszawa: Instytut Psychiatrii i Neurologii; 2014.

33. Sierosławski J. The ESPAD project: history and assumptions. Introduction to series of papers from the ESPAD study 1995-2015. Poland against the background of Europe. Alcohol Drug Addict 2018; 31: 1

34. Karlsson T, Österberg E. A scale of formal alcohol control policy in 15 European Countries. Nordic Studies on Alcohol and Drugs 2001; 18: 117-31.

35. Ysa T, Colom J, Albareda A, Ramon A, Carrion M, Segura L. Governance of addictions: European public policies. Oxford: Oxford University Press; 2014.

36. World Health Organization. Global status report on alcohol and health. Geneva; WHO: 2014.

37. Kraus L, Seitz NN, Piontek D, Molinaro S, Siciliano V, Guttormsson U, et al. 'Are The Times A-Changin'? Trends in adolescent substance use in Europe. Addiction 2018; doi: 10.1111/ add.14201.

38. de Looze M, Raaijmakers Q, ter Bogt T, Bendtsen P, Farhat T, Ferreira M, et al. Decreases in adolescent weekly alcohol use in Europe and North America: evidence from 28 countries from 2002 to 2010. European Journal of Public Health 2015; 25: 69-72.

39. Yeomans H. Blurred visions: experts, evidence and the promotion of moderate drinking. Sociological Review 2013; 61: 58-78.

40. Thompson KD, Stockwell T, Macdonald S. Is there a 'low-risk' drinking level for youth? The risk of acute harm as a function of quantity and frequency of drinking. Drug and Alcohol Review 2012; 31: 184-93.

41. De Visser RO, Birch JD. My cup runneth over: Young people's lack of knowledge of lowrisk drinking guidelines. Drug and Alcohol Review 2012; 31: 206-12. 
